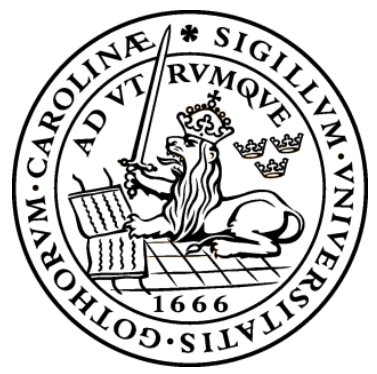

Lund University

School of Economics and Management

Department of Business Law

\title{
Double Taxation Resulting from the ATAD: \\ Is There A Relief?
}

by

\section{Annika Soom}

\section{HARN60 Master Thesis}

Master's Programme in European and International Tax Law

$2018 / 2019$

Spring semester 2019

Date of submission: 2019-06-07

Supervisor: Cécile Brokelind

Examiner: Sigrid Hemels

Author's contact information: annika.soom@gmail.com +37253308203 


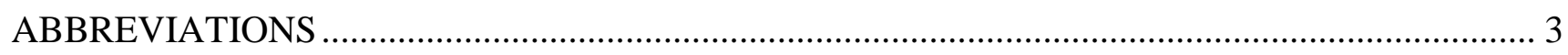

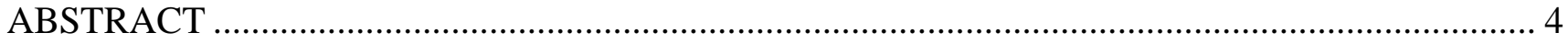

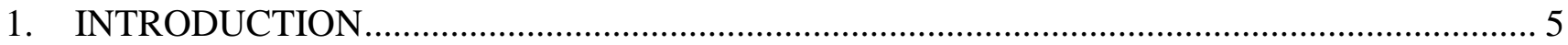

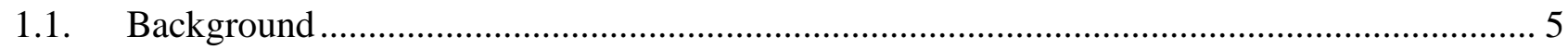

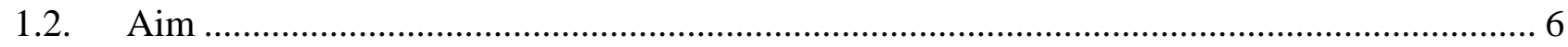

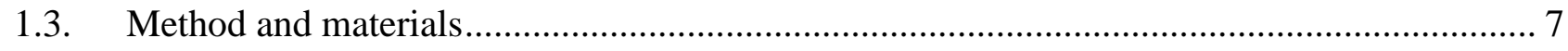

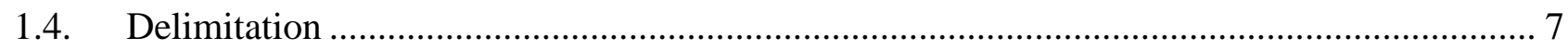

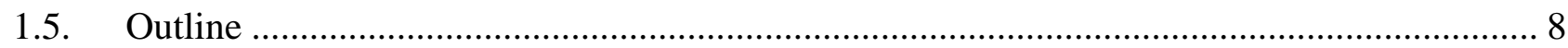

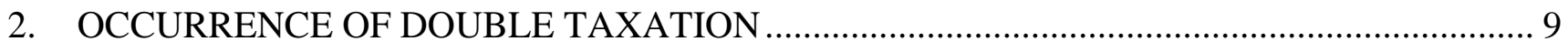

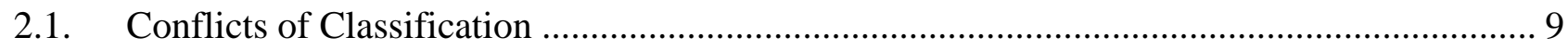

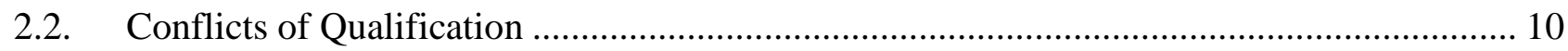

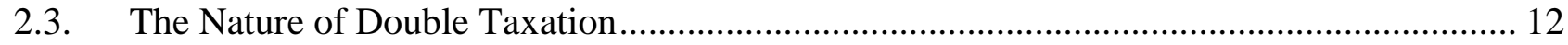

3. DOUBLE TAXATION RESULTING FROM THE IMPLEMENTATION OF INTEREST DEDUCTION LIMITATION AND CONTROLLED FOREIGN COMPANY RULES OF THE

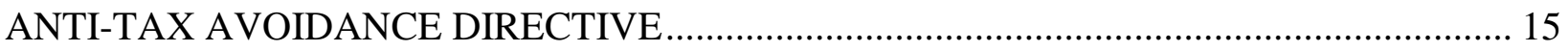

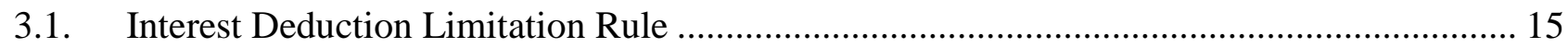

3.1.1. Double Taxation arising from Interest Deduction Limitation Rule ..................................... 17

3.2. Controlled Foreign Company Rules …………............................................................ 18

3.2.1. Double Taxation from Controlled Foreign Company Rules ............................................... 21

4. RELIEF FOR DOUBLE TAXATION RESULTING FROM THE INTEREST DEDUCTION LIMITATION AND CONTROLLED FOREIGN COMPANY RULES OF THE ANTI-TAX

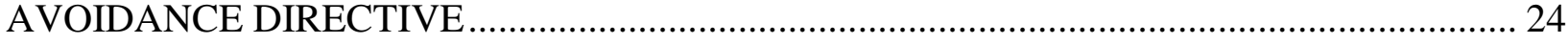

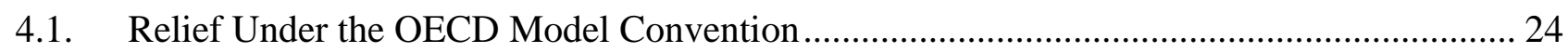

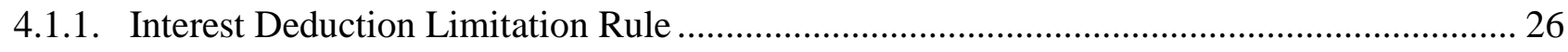

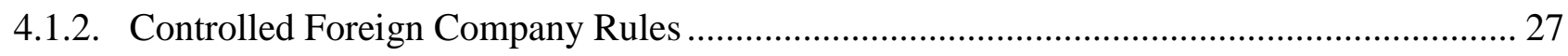

4.2. Relief Under European Union Legislation ……............................................................ 29

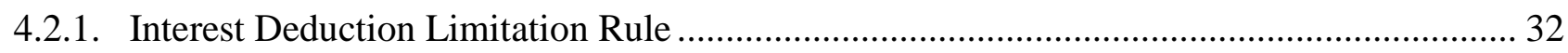

4.2.2. Controlled Foreign Company Rules ……………….................................................... 34

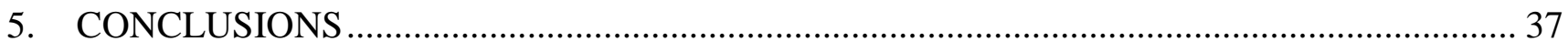

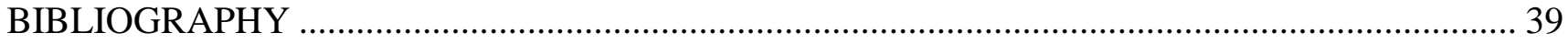




\section{ABBREVIATIONS}

ATAD

ATAD 2

BEPS

$\mathrm{CFC}$

CJEU

Commission

Council

EBITDA

$\mathrm{EU}$

EU Arbitration Convention

EU Dispute Directive

EUR

GAAR

Interest and Royalty Directive

MLI

OECD

OECD MC

Parent-Subsidiary Directive

SAAR

TEU

TFEU
Directive 2016/1164 of 12 July 2016 laying down rules against tax avoidance practices that directly affect the functioning of the internal market

Directive 2017/952 of 29 May 2017 amending directive 2016/1164 as regards hybrid mismatches with third countries

Base Erosion and Profit Shifting

Controlled Foreign Company

Court of Justice of the European Union

European Commission

Council of the European Union

Earnings Before Interest, Taxes, Depreciation and Amortization

European Union

Convention on the elimination of double taxation in connection with the adjustment of profits of associated enterprises

Directive 2017/1852 of 10 October 2017 on tax dispute resolution mechanisms in the European Union

Euro

General Anti Abuse Rule

Council Directive 2003/49/EC of 3 June 2003 on a common system of taxation applicable to interest and royalty payments made between associated companies of different Member States.

Multilateral Convention to Implement Tax Treaty Related Measures to Prevent BEPS

Organisation for Economic Co-operation and Development

OECD Model Convention on Income and Capital 2017 (full version)

Council Directive 2011/96/EU of 30 November 2011 on the common system of taxation applicable in the case of parent companies and subsidiaries of different Member States

Specific Anti Abuse Rule

Treaty on European Union

Treaty of Functioning of European Union 


\begin{abstract}
Despite of the ambitious aim of the ATAD, the adverse effect of double taxation caused by the implementation of it is unsolved. It is therefore up to taxpayers to solve the conflict of norms by identifying the correct source of law for eliminating double taxation.

The thesis focuses on the double taxation caused by the implementation of ATAD and identifying the correct source of law, if possible, to provide relief for such double taxation. As the potential sources of law, the OECD MC and European Union legislation has been analyzed. The scope of the thesis is limited to the rule on interest deduction limitation and CFC rules as provided in the ATAD.
\end{abstract}




\section{INTRODUCTION}

\subsection{Background}

By implementing the anti-tax avoidance directive (ATAD), ${ }^{1}$ Member States expand their taxing rights in a way which could lead to double taxation. Double taxation caused by the ATAD has been acknowledged also in the recital 5 of ATAD as a potential adverse effect. Despite of double taxation being deemed to be incompatible with the internal market, ${ }^{2}$ the ATAD does not foresee any obligation for Member States to provide a relief for double taxation other than economic double taxation arising from the actual dividend distribution by a controlled foreign company (CFC) or disposal of shares in the CFC. ${ }^{3}$ Therefore, it is up to a taxpayer to find a correct source of law to eliminate the double tax burden caused by the ATAD. As the tax treaty law, European Union (EU) law and to some extent the domestic legislation of Member States are all independent legal spheres, it is unclear which source of law would be applicable to provide relief for double taxation caused by the ATAD.

Since the introduction of the EU Anti-Tax Avoidance Package by the Commission on $28^{\text {th }}$ January $2016,{ }^{4}$ the scholars and tax experts have been analyzing several aspects of the ATAD. Nevertheless, the publications available at the time of this thesis do not examine the conflict of sources of law in connection with double taxation caused by the ATAD nor provide any guidance on correct source of law to eliminate the double tax burden.

Since all taxpayers subject to corporate income tax in the EU fall under the scope of the ATAD, ${ }^{5}$ ATAD aims to enforce a single tax principle in cross-border situations and interfere in the allocation of fair taxing rights. ${ }^{6}$ Furthermore, the ATAD obliges Member States to fight avoidance of domestic tax law even in wholly domestic situations. ${ }^{7}$ As a directive, the ATAD requires Member States to achieve the result aimed by it, however, Member States are free to choose most suitable form and method. ${ }^{8}$ The margin of discretion left to the Member States in combination with the extended opportunity to tax, increases also ATAD's potential to cause double taxation.

Double taxation is commonly divided as juridical and economic double taxation, without further discussion regarding the underlying conflict of classification or qualification. As it is evident from the case law of Court of Justice of the European Union (CJEU), juridical double taxation, despite of having adverse effect on the internal market, is generally ${ }^{9}$ not deemed to be a restriction of fundamental

\footnotetext{
${ }^{1}$ Council Directive (EU) 2016/1164 of 12 July 2016 laying down rules against tax avoidance practices that directly affect the functioning of the internal market. Official Journal L 193, 19.7.2016, pages 1-14.

2 This has been pointed out by the Commission already in 1996, for example see Commission of The European Communities. Taxation in the European Union. 20.03.1996. SEC(96) 487 final, page 13.

${ }^{3}$ ATAD, article 8(5) and (6).

${ }^{4}$ Communication from The Commission to The European Parliament and The Council. Anti-Tax Avoidance Package: Next steps towards delivering effective taxation and greater tax transparency in the EU. COM/2016/023 final.

${ }^{5}$ ATAD, recital 4.

${ }^{6}$ Dourado, A. P. The EU Anti Tax Avoidance Package: Moving Ahead of BEPS? INTERTAX, Volume 44, Issue 6 \& 7 , page 441.

${ }^{7}$ De Lillo, F. The Impact of the EU Anti-Tax Avoidance Package on the Exercise of National Tax Sovereignty in European Tax Integration: Law, Policy and Politics. Edited by Pistone, P. IBFD, 2018, section 16.4.1.

${ }^{8}$ TFEU, article 288.

${ }^{9}$ Except in case of discriminatory withholding tax on dividends, see for example judgement of 8 November 2007, Amurta, C379/05, EU:C:2007:655.
} 
freedoms but a consequence of parallel exercise of taxing rights and compatible with EU law. ${ }^{10}$ Therefore, EU primary law is most likely not a reliable source of law for providing a relief for juridical double taxation. Hence, it is under the jurisdiction of Member States to eliminate such double tax burden of a taxpayer. On the other hand, the CJEU found EU primary law applicable in case the discriminative domestic legislation led to the economic double taxation. ${ }^{11}$ Therefore, EU primary law could be a reliable source of law for eliminating the economic double taxation.

In addition to EU primary law, disputes of double taxation could be solved under the Arbitration Convention ${ }^{12}$ or Dispute Resolution Directive. ${ }^{13}$ Moreover, Member State's right to impose taxes could be restricted by EU secondary legislation - in the context of ATAD, namely by the Interest and Royalty Directive $^{14}$ and Parent-Subsidiary Directive. ${ }^{15}$

To solve the problem of double taxation, the OECD Model Convention on Income and Capital (OECD $\mathrm{MC}$ ) could also be an applicable source of law. However, it has been discussed by the scholars that the scope of articles $23 \mathrm{~A}$ and $23 \mathrm{~B}$ could be limited only to juridical double taxation. ${ }^{16}$ Should one agree with such interpretation, it would be up to the states to hold bilateral negotiations to provide relief for the economic double taxation falling outside the scope of articles $23 \mathrm{~A}$ and $23 \mathrm{~B} .{ }^{17}$ However, scholars supporting the opposing view agree that only economic double taxation resulting from classical corporate tax system should be excluded from the scope of OECD MC. Therefore, the relief of double taxation under the OECD MC depends above all on the approach chosen.

\subsection{Aim}

As the implementation of the ATAD could lead to the double taxation resulting from the conflict of norms, the first aim of this thesis is to detect which sources of law could be applicable to eliminate the problem of double taxation. Is it EU primary law, EU secondary legislation or tax treaty law? Secondly, the purpose of this thesis is to identify the source of law based on which the double taxation could be relieved after the implementation of the ATAD. In other words, to establish if there is any relief for double taxation resulting from the ATAD? To analyze the impact of the ATAD on double taxation, the thesis aims to i) distinguish between classification and qualification conflicts; ii) analyze the nature of

\footnotetext{
${ }^{10}$ For example, judgement of 12 February 2009, Margarete Block, C-67/08, EU:C:2009:92, paragraph 31. Wattel, P. Conceptual Background of the CJEU Case Law in Direct Tax Matters. European Tax Law. Volume 1 - General Topics and Direct Taxation. 7th Student edition. Edited by Wattel, P., Marres, O., Vermuelen, H. Deventer: Wolters Kluwer, 2018 , page 316 and case law cited.

${ }^{11}$ For example, judgement of 13 November 2012, Test Claimants in the FII Group Litigation, C-35/11, EU:C:2012:707, paragraph 38 and case law cited.

12 90/436/EEC: Convention on the elimination of double taxation in connection with the adjustment of profits of associated enterprises. Official Journal L 225, 20.8.1990, pages 10-24.

${ }^{13}$ Council Directive 2017/1852 of 10 October 2017 on tax dispute resolution mechanisms in the European Union, Official Journal L 265, 14.10.2017, p. 1-14.

${ }^{14}$ Council Directive 2003/49/EC of 3 June 2003 on a common system of taxation applicable to interest and royalty payments made between associated companies of different Member States. Official Journal L 157, 26.6.2003, pages 49-54.

${ }^{15}$ Council Directive 2011/96/EU of 30 November 2011 on the common system of taxation applicable in the case of parent companies and subsidiaries of different Member States. Official Journal L 345, 29.12.2011, pages 8-16.

${ }^{16}$ Lang, M. The Application of the OECD Model Tax Convention to Partnerships. A Critical Analysis of the Report Prepared by the OECD Committee on Fiscal Affairs. Linde, 2000, page 29.

${ }^{17} \mathrm{OECD}$ MC Commentaries on article 23A and B, paragraph 2.
} 
double taxation; iii) examine the rule on interest deduction limitation and CFC rules of the ATAD; and iv) identify the correct source of law to eliminate the double taxation, if possible.

\subsection{Method and materials}

In order to provide answers to the legal questions of this thesis and determine the relevant sources of law, ${ }^{18}$ the traditional legal dogmatic method has been used. By using the aforesaid method, research of current positive law as it has been stated in the European and international law, case law and the literature has been conducted, ${ }^{19}$ followed by the legal dogmatic process of interpretation. ${ }^{20}$

The primary sources for the research are the relevant EU law in force and the OECD MC. Furthermore, articles published by legal scholars, books, commentaries as well as preparatory work of the ATAD has been analyzed. As the ATAD is a reflection of the OECD BEPS project at the EU level, also BEPS Action 3 and 4 final reports have been examined to the extent relevant for this thesis.

The thesis is based on the materials published as of June 1, 2019. Later publications, if any, have not been examined.

\subsection{Delimitation}

The scope of this thesis is limited to the potential corporate double taxation resulting from the minimum standard stated for interest deduction limitation and CFC rules in the ATAD. The rule on interest deduction limitation and CFC rules have been chosen as at the first glance there seems to be no clear tool to provide relief for the caused double taxation.

This analysis does not include double taxation arising from the implementation of other anti-avoidance measures of the ATAD (i.e. articles 5, 6 and 9) or double taxation resulting from the alternative measures which Member States may choose to apply to achieve higher level of protection for their corporate tax system. The general anti abuse rule (GAAR) has been excluded as the focus of this thesis is on specific anti abuse measures (SAAR). This thesis does also not analyze the exit taxation as article 5(5) of the ATAD requires Member States to accept the value of the assets established by the other Member State and provides therefore a solution for double taxation without the need to apply an additional source of law. Since the recital 30 of ATAD $2^{21}$ makes explicit reference to the applicability of secondary legislation and its priority in case of conflicts of norms, the hybrid mismatches also fall out of the scope of this thesis.

The analysis of any directive in this thesis is based on the wording of a specific directive as adopted by the Council and does not include possible variations Member States may implement. Since more than 3000 tax treaties around the world, including tax treaties between Member States, follow the OECD

\footnotetext{
${ }^{18}$ Douma, S. Legal Research in International and EU Tax Law. Kluwer-Deventer, 2014, page 35.

${ }^{19}$ Ibid, page 18 .

${ }^{20}$ Ibid, page 38 .

${ }^{21}$ Council Directive (EU) 2017/952 of 29 May 2017 amending Directive (EU) 2016/1164 as regards hybrid mismatches with third countries. Official Journal L 144, 7.6.2017, pages 1-11.
} 
$\mathrm{MC},{ }^{22}$ any examination of tax treaties is based on the OECD MC 2017 full version published by the OECD in 2019, except otherwise stated, taking into consideration also the multilateral instrument (MLI). No analysis has been concluded based on any specific tax treaty in force.

\subsection{Outline}

To achieve the purposes of this thesis, it has been divided into five chapters. After the introductory chapter, chapter 2 analyzes the occurrence of double taxation including some underlying conflicts of classification and qualification. In chapter 3, the double taxation resulting from the rule on interest deduction limitation as well as CFC rules has been analyzed. Chapter 4 focuses on the EU legislation and OECD MC as sources of law to analyze whether they could eliminate double tax burden arising from aforementioned SAARs. Findings of the thesis have been summarized in chapter 5.

22 Tax treaties: update to OECD Model Tax Convention released. OECD press release from 18.12.2017. Available online http://www.oecd.org/tax/treaties/tax-treaties-2017-update-to-oecd-model-tax-convention-released.htm Accessed 18.03.2019. 


\section{OCCURRENCE OF DOUBLE TAXATION}

\subsection{Conflicts of Classification}

Despite the fact that there is no commonly agreed understanding how, if at all, conflicts causing double taxation and double non-taxation in the context of tax treaty law should be divided or defined, ${ }^{23}$ the subsequent analysis is based on the approach used for example by professors Klaus Vogel and Alexander Rust, according to whom the conflicts in question can be divided as conflicts of classification and conflicts of qualification. ${ }^{24}$

The conflict of classification, as one cause of cross-border double taxation, occurs when states give different interpretation to the facts or provisions of a tax treaty ${ }^{25}$ and subject the same income therefore simultaneously to different articles of the treaty. ${ }^{26}$ This could be the case for example as regards the payment of interest of which the creditor shares the risks run by the borrower. In such situation, it should be analyzed in the light of specific facts and circumstances of the payment whether the payment should be treated as interest or dividend. ${ }^{27}$ Such double taxation, as a consequence of different prerequisites that establish the tax liability, is a result of a classification conflict. ${ }^{28}$

Since tax treaties include distributive rules which limit the applicability of states' domestic tax law ${ }^{29}$ but do not provide rules linking the income to a specific taxpayer, ${ }^{30}$ the decision of attribution of income is left as a matter of domestic law. ${ }^{31}$ The tax treaties do generally not act as arbitrators to determine which state's attribution is correct. ${ }^{32}$ Therefore, double taxation caused by the conflict of classification is not solved by a tax treaty itself and does not oblige the state of residence to grant relief. Instead states should seek to resolve the question of double taxation through mutual agreement procedure. ${ }^{33}$

Mutual agreement procedure requires that states follow rules of interpretation of international agreements, first and foremost, as established by the Vienna Convention on the Law of Treaties, taking into consideration the text of the tax treaty as well as its purpose. ${ }^{34}$ However, the mutual agreement procedure does not require states to effectively solve the problem of double taxation, unless the states have included mandatory arbitration clause in their tax treaties. ${ }^{35}$ Nevertheless, even then, the states are

\footnotetext{
${ }^{23}$ For example, see Lang, M. Qualification Conflicts. Global Tax Treaty Commentaries. IBFD, 2018, section 1.2.

${ }^{24}$ Vogel, K., Rust, A. Klaus Vogel on Double Taxation Conventions, $4^{\text {th }}$ edition, edited by Reimer, E., Rust, A., 2015. Introduction at marginal number 120-121, pages 54-55.

${ }^{25}$ OECD MC Commentaries on article 23A and B, paragraph 32.5.

26 Äimä, K. Key practical issues to eliminate double taxation of business income. Classification Conflicts: The Cross-Border Tax Treatment of the Profit Share of Limited Partners. IFA Cahiers, Volume 96B, 2011, page 311.

${ }^{27}$ OECD MC Commentaries on article 10, paragraph 25.

${ }^{28}$ Vogel, K., Rust, A., Klaus Vogel on Double Taxation Conventions., op. cit. Introduction at marginal number 121, page 55.

${ }^{29}$ Ibid at marginal number 30, page 23.

${ }^{30}$ Ault, H. J., Issues Related to the Identification and Characteristics of the Taxpayer. Bulletin for International Taxation, 2002. Volume 56, No. 6, page 263.

${ }^{31}$ Rust, A. Klaus Vogel on Double Taxation Conventions, $4^{\text {th }}$ edition, edited by Reimer, E., Rust, A., 2015 . Article 1 at marginal number 16, page 106.

${ }^{32} \mathrm{Ibid}$ at marginal number 60, page 129 and referred article.

${ }^{33}$ OECD MC Commentaries on article 23A and B, paragraph 32.5.

${ }^{34}$ United Nations. Vienna Convention on the Law of Treaties, 23 May 1969, United Nations, Treaty Series, vol. 1155 , article 31.

${ }^{35}$ OECD MC Commentaries on article 25, paragraph 64.
} 
not obliged to provide any relief for double tax burden during the mutual agreement procedure nor compensate the lost opportunity to use the money. ${ }^{36}$

At the level of EU, the classification conflicts could also be solved to the limited extent by the CJEU. The CJEU would be entitled to eliminate the economic double taxation resulting from the different interpretation of facts or tax treaty provisions in case of unjustified cross-border discrimination. This would be possible only when Member States have provided the CJEU with jurisdiction to rule on a tax treaty. ${ }^{37}$ However, as the field of direct taxation is not fully harmonized, the Council nor the Commission are able to establish consistent interpretation in a way which would eliminate all classification conflicts within the EU.

\subsection{Conflicts of Qualification}

In addition to classification conflicts, double taxation could also be a result of a positive qualification conflict where both contracting states of a treaty want to tax the income. ${ }^{38}$ The conflict of qualification can be understood as a problem of income categorization for treaty purposes ${ }^{39}$ arising from the use of terms derived from states' domestic legislation ${ }^{40}$ and applying therefore different distributive rules of a tax treaty to the same income. ${ }^{41}$ As such terms are not defined by the tax treaty itself, states are applying the meaning the term has in each state's domestic legislation, thereby steering to conflicts caused by the different meaning of the same term.

Double taxation arising from the qualification conflicts caused by different provisions of a domestic legislation is eliminated by article $23 \mathrm{~A}$ or $23 \mathrm{~B}$ of the OECD MC. Under the aforementioned provisions, the state of residence is required to apply an exemption or credit method, notwithstanding the qualification conflict. ${ }^{42}$ Nevertheless, actual double taxation is required and the mere existence of qualification conflict is not deemed to be sufficient to oblige the state of residence to eliminate the double taxation under the OECD MC. ${ }^{43}$

Double taxation arising from the qualification conflicts can be solved, to some extent, also by a tax treaty itself. In particular, where the tax treaty expressly defines specific term. ${ }^{44}$ Furthermore, it has been discussed that qualification conflicts are also solved by the article 3(2) of OECD MC ${ }^{45}$ which specifies that undefined terms in a tax treaty should have the meaning that such term has under the domestic law of the state applying the treaty, unless the context requires otherwise or the tax authorities

\footnotetext{
${ }^{36}$ Ismer, R. Klaus Vogel on Double Taxation Conventions, $4^{\text {th }}$ edition, edited by Reimer, E., Rust, A., 2015. Article 25 at marginal number 28, page 1795 .

${ }^{37}$ Judgement of 12 September 2017, Austria vs Germany, C-648/15, EU:C:2017:664, paragraph 27.

${ }^{38}$ Rust, A. The New Approach to Qualification Conflicts has its Limits. Bulletin for International Taxation, 2003. Volume 57, No 2, page 48 .

39 Jones, J.F.A. Qualification Conflicts: The Meaning of Application in Article 3(2) of the OECD Model. Festschrift für Karl Beusch zum 68. Geburtstag am 31. Oktober 1993. Edited by Beisse, H., Lutter, M., Närger, H. New York: de Gruyter, page 43.

${ }^{40}$ Vogel, K., Rust, A., Klaus Vogel on Double Taxation Conventions., op. cit., Introduction at marginal number 120 , page 54.

${ }^{41}$ Gupta, V. K. Conflicts of Qualification and Conflicts of Allocation of Income. Conflicts of Qualification in Tax Treaty Law. Edited by Burgstaller, E., Haslinger, K. Linde, 2007, page 41.

42 OECD MC Commentaries on article 23A and B, paragraph 32.3.

${ }^{43}$ Lang, M. 2008 OECD Model: Conflicts of Qualification and Double Non-Taxation. Bulletin for International Taxation, 2009. Volume 63, No 5, page 205.

${ }^{44}$ Vogel, K., Rust, A., Klaus Vogel on Double Taxation Conventions., op. cit., Introduction at marginal number 124 , page 56.

${ }^{45} \mathrm{Ibid}$ at marginal number 125, page 57.
} 
have agreed on a different meaning. However, it is questionable whether article 3(2) solves the qualification conflict or actually prevents such conflict by determining which state's domestic meaning of the undefined treaty term is applicable.

In situations where the tax treaty does not provide any solution to the qualification conflict, there are three most widely discussed solutions proposed by the scholars: i) lex fori qualification, meaning that each state qualifies tax treaty terms according to its own domestic legislation; ii) source state qualification which requires both states to follow the qualification of the state in which the income derives; and iii) autonomous qualification by which both states seek to establish a consistent qualification of a term. The fourth solution also considered, but not widely discussed, is the qualification in accordance with the resident state's legislation. ${ }^{46}$ Argument in favor of the latter one can be found from the traditional systematic approach according to which the taxation in resident state is a rule and taxation in the source state is the exception. ${ }^{47}$

As the domestic law and tax treaty law are two independent legal spheres with their own definitions, states should prefer to establish consistent qualification of a term (i.e. apply autonomous qualification) over other methods while providing solution to a qualification conflict, ${ }^{48}$ irrespective of its possible restrictive impact on states' sovereignty. ${ }^{49}$ However, in practice the combination of different methods may work the best, depending on the purpose of the interpretation. ${ }^{50}$

Within the EU, the qualification conflicts are avoided to the extent the term is defined by the legislation of EU which has become part of domestic legislation of Member States. ${ }^{51}$ In the field of direct taxation, the EU has up to now adopted only directives which Member States are obliged to transpose into their domestic legislation. Irrespective of the discretion Member States may have while implementing a directive, they are required to achieve the results envisaged by it and apply the law of EU correctly. ${ }^{52}$ This, however, would be difficult to attain when Member States would be entitled to change the definitions established by the directive during the implementation process. Hence, it could be argued that the EU secondary legislation has eliminated double taxation resulting from a qualification conflict by introducing EU-wide autonomous qualification.

On the other hand, shared competence in the field of direct taxation ${ }^{53}$ means that qualification conflicts in unregulated areas of direct taxation would still be likely to occur and hinder the internal market. Due to the shared competence and Member States' sovereignty, it is doubtful that the CJEU would require Member States to agree on a consistent qualification of a term in applicable tax treaty. Especially taking

\footnotetext{
${ }^{46}$ Ibid at marginal number 124 , page 56.

${ }^{47}$ Ibid at marginal number 133, page 60.

${ }^{48}$ Ibid at marginal number 127, page 57.

${ }^{49}$ Pleil, C., Schwibinger, S. Confronting Conflicts of Qualification in Tax Treaty Law: The Principle of Common Interpretation and the New Approach Revisited. World Tax Journal, 2018. Volume 10, No 3, page 445.

${ }^{50}$ Vogel, K., Rust, A., Klaus Vogel on Double Taxation Conventions., op. cit., Introduction at marginal number 136 , page 61.

${ }^{51}$ Jones, J.F.A. Treaty Interpretation. Global Tax Treaty Commentaries. IBFD, 2018, section 4.5.4.

52 TEU article 4(3) and TFEU article 288.

53 TFEU, article 4. TEU, article 5. See also, Szudoczky, R., Weber, D. Constitutional Foundations: EU Tax Competence; Legal Basis for Tax Integration; Sources and Enactment of EU Tax Law. European Tax Law. Volume 1 - General Topics and Direct Taxation. 7th Student edition. Edited by Wattel, P., Marres, O., Vermuelen, H. Deventer: Wolters Kluwer, 2018 , page 10.
} 
into consideration the CJEU's position regarding its lack of jurisdiction to interpret tax treaties, ${ }^{54}$ unless Member States have provided the CJEU with such jurisdiction. ${ }^{55}$ This, however, should be distinguished from the cases where the CJEU interprets EU secondary legislation and applies OECD MC definitions while doing so. ${ }^{56}$

Therefore, in case of conflict of qualification, one should first seek a solution from a tax treaty. Should the tax treaty provide no solution, the domestic legislation of Member States should be examined. As the tax treaty makes generally no direct reference to the EU law, EU legislation would not be an independent source of law to solve the conflict of qualification. However, once becoming part of the domestic legislation of Member States, EU law would indirectly be the applicable source of law to solve the conflict of qualification. ${ }^{57}$

\subsection{The Nature of Double Taxation}

Despite the conflict of classification and conflict of qualification being the underlying problem of double taxation, international double taxation is more typically described as juridical and economic double taxation.

Juridical double taxation can be defined as simultaneous exercise of resident and source state's taxing rights on the same taxpayer in respect of the same income for identical period. ${ }^{58}$ Such double tax burden could be a result of three conflicts of taxing rights: i) both states deem the taxpayer as its resident (resident-resident conflict); ii) one state exercises its taxing rights over the income as a resident state while the other state taxes the income as derived from its territory (resident-source conflict); or iii) both states deem the income derived from its territory (source-source conflict). ${ }^{59}$

In addition to juridical double taxation, it is important to distinguish the double tax burden caused by two or more states taxing the same income for the same period in the hands of different taxpayers economic double taxation. Economic double taxation could result from successive taxation of income which is passed from one person to another, such as taxation of a profit at the level of a company and its shareholders, ${ }^{60}$ or for example from a classification conflict between states. ${ }^{61}$

Despite double taxation being hindrance to the development of international trade and investments, it is not forbidden nor contrary to the international law as long as it results from the parallel exercise of domestic legislation of states which itself complies with the international law. Thus, there is also no

\footnotetext{
${ }^{54}$ Judgement of 6 December 2007, Columbus Container Services, C-298/05, EU:C:2007:754, paragraph 46 and judgement of 16 July 2009, Damseaux, C-128/08, EU:C:2009:471, paragraph 22.

55 Judgement of 12 September 2017, Austria vs Germany, C-648/15, EU:C:2017:664, paragraph 27.

${ }^{56}$ For example judgement of 26 February 2019, N Luxembourg 1, joined cases C-115/16, C-118/16, C-119/16 and C-299/16, EU:C:2019:134. See also, Wattel, P. Relevance of (Deviations from) the OECD Model and Commentary in ECJ Income Tax Case Law. Departures from the OECD Model and Commentaries. Reservations, observations and positions in EU law and tax treaties. Edited by Maisto, G. IBFD, 2014, page 102.

${ }^{57}$ Jones, J.F.A. Treaty Interpretation., op. cit., section 4.5.4.

${ }^{58}$ OECD MC Commentaries. Introduction, paragraph 1.

${ }^{59}$ OECD MC Commentaries on article 23A and B, paragraph 3.

${ }^{60}$ Danon, R. J. Conflicts of Attribution of Income Involving Trusts under the OECD Model Convention: The Possible Impact of the OECD Partnership Report. Intertax, 2004. Volume 32, Issue 5, page 215.

${ }^{61}$ Van Raad, K. General Report. Recognition of foreign enterprises as taxable entities. IFA Cahiers, Volume 73A, 1988 , page 33.
} 
general rule establishing which state should withdraw its taxing rights. ${ }^{62}$ As the double taxation is not desirable, states generally try to solve it unilaterally or through bilateral tax treaties. ${ }^{63}$

The aforementioned distinction between two types of double taxation is necessary as pursuant to the OECD MC Commentaries, the OECD MC aims to provide relief only for juridical double taxation. ${ }^{64}$ Since the OECD MC attempts to avoid only double taxation covered by its scope, double taxation beyond the scope of the OECD MC has to be accepted. ${ }^{65}$ Thus, the economical double taxation which generally falls outside of the scope of OECD MC is not eliminated by the tax treaty itself but only when agreed by the contracting states. ${ }^{66}$ However, some scholars are of the opinion that the OECD MC excludes only economic double taxation resulting from successive taxation, in other words economic double taxation arising from the classical corporate tax system, ${ }^{67}$ and the OECD MC is also applicable to provide a relief from economic double taxation which is a result of a classification conflict. ${ }^{68}$

Some academics, advocating the aforementioned approach, point out that nothing in the wording of OECD MC distributive articles suggests, except article 10(2) of OECD MC, ${ }^{69}$ that their application would be limited only to juridical double taxation, leaving those articles ineffective in case of economic double taxation stemming from classification conflicts. ${ }^{70}$ Instead of making the application of distributive rules conditional on the allocation of income to the same taxpayer, namely determining the recipient of the income, ${ }^{71}$ distributive rules only deal with the allocation of taxing rights between the contracting states. ${ }^{72}$ Furthermore, it has been discussed that the context ${ }^{73}$ as well as the object and purpose of the OECD MC does not support the interpretation which excludes economic double taxation, other than the one resulting from the classical corporate tax system, from the scope of distributive rules as distributive rules aim to eliminate double taxation irrespective of the divergences existing between states regarding the income attribution. ${ }^{74}$

\footnotetext{
${ }^{62}$ Vogel, K., Rust, A. Klaus Vogel on Double Taxation Conventions., op. cit., Introduction at marginal number 11 , pages $14-15$. ${ }^{63}$ Monsenego, J. Taxation of Foreign Business Income within the European Internal Market. An Analysis of the Conflict between the Objective of Achievement of the European Internal Market and the Principles of Territoriality and Worldwide Taxation. IBFD Doctorial Series, 2012. Volume 22, page 61.

${ }^{64}$ OECD MC Commentaries on article 23A and B, paragraphs 1 and 2.

${ }^{65}$ Lang, M., The Application of the OECD Model Tax Convention to Partnerships., op. cit., page 29.

${ }^{66}$ OECD MC Commentaries on article 23A and B, paragraph 2. OECD MC provides relief for economical double taxation only as regards transfer pricing adjustments by requiring to make a corresponding adjustment (article 9).

${ }^{67}$ A system of taxation under which tax is charged on profits realized at the corporate level and again on distribution of the net profits, at the individual shareholder level, with no mitigation of the resulting double taxation. The term is generally limited to the national context, e.g. where the same state taxes both company and shareholder. IBFD Tax Glossary. Available online https://online.ibfd.org/kbase/\#topic=doc\&url=/highlight/collections/itg/html/itg_classical_system.html\&q=-

classical\&WT.z_nav=Search Accessed 17.04.2019.

${ }^{68}$ Kuźniacki, B. The Need to Avoid Double Economic Taxation Triggered by CFC Rules under Tax Treaties, and the Way to Achieve It. INTERTAX, 2015. Volume 43, Issue 12, page 764. Danon, R. J., Salomé, H. Avoidance of Double Non-Taxation in Switzerland. Avoidance of Double Non-Taxation. Edited by Lang, M. Linde, 2003, page 400.

${ }^{69}$ Article 10(2) of OECD MC reads as follows: "This paragraph shall not affect the taxation of the company in respect of the profits out of which the dividends are paid."

${ }^{70}$ Danon, R. J., Conflicts of Attribution of Income Involving Trusts under the OECD Model Convention., op. cit. page 216.

${ }^{71}$ Kuźniacki, B., op. cit., page 762.

${ }^{72}$ Danon, R. J., Salomé, H., op. cit., page 399.

${ }^{73}$ Kuźniacki, B., op. cit., page 764.

${ }^{74}$ Danon, R. J., Conflicts of Attribution of Income Involving Trusts under the OECD Model Convention., op. cit., pages 216-217.
} 
The distinction made by the Commentaries of OECD MC between juridical and economic double taxation has deemed to be irrelevant and, in the light of other references in the Commentaries, ${ }^{75}$ it has been questioned whether narrowing the scope of OECD MC only to the juridical double taxation could really have been the intention. ${ }^{76}$

Based on the above, it can be concluded that the OECD MC aims to, irrespective of the references according to which it is limited only to solve the problem of juridical double taxation, provide relief also in cases of economic double taxation resulting from classification conflicts. The author agrees that providing relief for double taxation cannot operate as the underlying premise of OECD MC in every situation. ${ }^{77}$ However, it is plausible that only economic double taxation arising from the classical corporate tax system should be excluded from the scope of OECD MC. As demonstrated by the scholars, the reverse approach is not supported by the wording, object nor the purpose of OECD MC. Furthermore, the author agrees with professor Vogel that the conceptual distinction between the juridical and economic double taxation is insignificant as the application of a tax treaty depends on the interpretation of a respective treaty and is not affected by the characteristics of a double taxation. ${ }^{78}$ Therefore, the OECD MC would be relevant source of law to provide relief for juridical as well as economic double taxation.

\footnotetext{
${ }^{75}$ For example, OECD MC Commentaries on article 10, paragraph 41.

${ }^{76}$ Danon, R. J., Conflicts of Attribution of Income Involving Trusts under the OECD Model Convention., op. cit., page 217.

${ }^{77}$ Lang, M., The Application of the OECD Model Tax Convention to Partnerships., op. cit., page 29.

${ }^{78}$ Vogel, K., Rust, A., Klaus Vogel on Double Taxation Conventions., op. cit. Introduction at marginal number 5, page 13.
} 


\section{DOUBLE TAXATION RESULTING FROM THE IMPLEMENTATION OF INTEREST DEDUCTION LIMITATION AND CONTROLLED FOREIGN COMPANY RULES OF THE ANTI-TAX AVOIDANCE DIRECTIVE}

\subsection{Interest Deduction Limitation Rule}

Tax deductibility of interests within associated companies compared to non-deductible profit distributions provide taxpayers with an opportunity to optimize their tax base. Decreasing a tax burden of a company in high tax jurisdiction through debt-financing by shareholders or other group members in a low tax jurisdiction has been considered as one of the simplest ways to achieve cross-border profit shifting. ${ }^{79}$ In connection with debt-financing, the OECD has identified three most typical scenarios used by multinational enterprises for cross-border profit shifting: i) high level of external debt is located to group companies in high-tax jurisdictions; ii) internal debt from intragroup loans is used to generate interest deductions which exceed the actual third party interest expenses; and iii) use of interest deductions to generate tax exempt income in high-tax jurisdictions. ${ }^{80}$

To combat the problem of asymmetric treatment of debt and equity for tax purposes, states have implemented thin capitalization rules. Thin capitalization rules typically establish a safe harbor and disallow the deductibility of interest payments between related parties or third parties in back-to-back financing schemes which exceed stated debt-to-equity ratio. ${ }^{81}$ Depending on the approach chosen, thin capitalization rules could instead of denying the deduction of an excessive interest re-characterize the excessive amount of interest as a dividend income. ${ }^{82}$

In order to discourage EU taxpayers to use interest expenses as a way of profit shifting ${ }^{83}$ and encourage the use of equity instead of debt, ${ }^{84}$ the ATAD establishes interest deduction limitation rule following the best practices developed by the OECD in BEPS Action $4 .{ }^{85}$ Article 4 of the ATAD establishes a fixed ratio and requires Member States to limit the amount of deductible borrowing costs (i.e. interest expenses, economically equivalent costs and other expenses incurred in connection with the raising of funds ${ }^{86}$ ) in a given tax period. Member States are obliged to limit the deductibility of exceeding borrowing costs at least by $30 \%$ of taxpayer's EBITDA which excludes any tax-exempt income. Thereby the interest deduction limitation rule functions as a rule of allocation reinforcing the principle

\footnotetext{
${ }^{79}$ Makhmudova, K. Conflicts of Qualification and Thin Capitalisation Rules. Conflicts of Qualification in Tax Treaty Law. Edited by Burgstaller, E., Haslinger, K. Linde, 2007, page 253.

${ }^{80}$ OECD. Limiting Base Erosion Involving Interest Deductions and Other Financial Payments, Action 4. Final Report, OECD/G20 Base Erosion and Profit Shifting Project. OECD Publishing, Paris, 2015, page 11.

${ }^{81}$ Dourado, A. The Interest Limitation Rule in the Anti-Tax Avoidance Directive (ATAD) and the Net Taxation Principle. EC Tax Review, 2017. Volume 26, Issue 3, page 113 and cited article. Makhmudova, K., op. cit., page 264.

${ }^{82}$ Arnold, B. J. International Tax Primer. Third edition. Wolters Kluwer, 2018, page 118.

${ }^{83}$ Van Os, P. Interest Limitation under the Adopted Anti-Tax Avoidance Directive and Proportionality. EC Tax Review, 2016. Volume 25, Issue 5, page 190.

${ }^{84}$ Lobita, J. C. The ATAD's Interest Limitation Rule - A Step Backwards? European Taxation, 2019. Volume 59, No. 2/3, page 63 and Dourado, A. The Interest Limitation Rule in the Anti-Tax Avoidance Directive (ATAD) and the Net Taxation Principle., op. cit., page 119 .

${ }^{85}$ Ginevra, G. The EU Anti-Tax Avoidance Directive and the Base Erosion and Profit Shifting (BEPS) Action Plan: Necessity and Adequacy of the Measures at EU level. INTERTAX, 2017. Volume 45, Issue 2, page 121.

${ }^{86}$ ATAD, article 2(1).
} 
of territoriality ${ }^{87}$ and connects the amount of deductible interests with the taxable economic activity of a taxpayer. ${ }^{88}$

Unlike traditional thin capitalization rules, the application of interest deduction limitation rule in the ATAD is not restricted to intra-group or cross-border situations. On the contrary, as a general rule it should apply to all kind of loans - intra-group, third party, between associated and standalone companies as well as loans granted in domestic and cross-border situations, ${ }^{89}$ raising thereby also questions regarding the proportionality of the measure. ${ }^{90}$ Especially as regards third party loans which are provided generally in accordance with the market conditions and do not entail a risk of abuse targeted by the ATAD.

By way of derogation, Member States are entitled to allow deduction of borrowing costs up to EUR $3,000,000$ - so called safe harbor, or without limitation in case the taxpayer is a standalone entity not being a part of a consolidated group for financial accounting purposes and has no associated enterprise or permanent establishment, ${ }^{91}$ thereby comprising low risk of aggressive tax planning. ${ }^{92}$ Furthermore, Member States may exclude from the scope of interest deduction limitation rule loans which have been granted before 17 June 2016 and have not been modified since the adoption of the ATAD as well as loans which are used to fund specific long-term public infrastructure projects. ${ }^{93}$ Member States are also entitled to exclude financial undertakings from the scope of interest deduction limitation rule. ${ }^{94}$ To be precise, Member States have in total six alternatives for implementing interest deduction limitation rule stated in the ATAD article $4 .{ }^{95}$ However, since the ATAD lays down only a minimum standard, Member States are not obliged to implement any derogations which would benefit taxpayers.

One of such derogations Member States may implement is a carry forward and carry back mechanism of exceeding borrowing costs. According to the article 4(6) of the ATAD, Member States have three options for introducing such derogation: i) carry forward of exceeding borrowing costs without any time limit; ii) carry forward of exceeding borrowing costs without time limit together with the possibility to carry back non-deductible borrowing costs up to three years; or iii) carry forward of exceeding borrowing costs without time limitation together with the carry forward of unused interest capacity for up to five years.

The abovementioned carry forward and carry back rules for unused interest capacity or exceeding borrowing costs are aimed to provide taxpayer a relief in case the application of interest deduction limitation rule would otherwise cause double taxation. ${ }^{96}$

\footnotetext{
${ }^{87}$ Dourado, A. The Interest Limitation Rule in the Anti-Tax Avoidance Directive (ATAD) and the Net Taxation Principle., op. cit., page 117 .

${ }^{88}$ Tell, M. Interest Limitation Rules in the Post-BEPS Era. INTERTAX, 2017. Volume 45, Issue 11, page 752.

${ }^{89}$ ATAD, recital 7.

${ }^{90}$ Smit, D. The Anti-Tax-Avoidance Directive (ATAD). European Tax Law. Volume 1 - General Topics and Direct Taxation. 7th Student edition. Edited by Wattel, P., Marres, O., Vermuelen, H. Deventer: Wolters Kluwer, 2018, page 251.

${ }^{91}$ ATAD article 4(3).

92 Tell, M., op. cit., page 755 .

${ }^{93}$ ATAD, article 4(4).

${ }^{94} \mathrm{Ibid}$, article 4(7).

${ }^{95}$ Ginevra, G., op. cit., page 121.

${ }^{96}$ OECD. Limiting Base Erosion Involving Interest Deductions and Other Financial Payments, Action 4., op. cit., paragraph 159.
} 


\subsubsection{Double Taxation arising from Interest Deduction Limitation Rule}

The problem of double taxation resulting from the interest deduction limitation rule is mainly connected to the de minimis nature of the ATAD. Since the unilateral application of interest limitation rule by one Member State could have cross-border impact, Member States "may", pursuant to the wording of article 4(6), implement a mechanism for carrying forward and back unused interest capacity or exceeding borrowing costs. This mechanism should ideally eliminate double taxation arising from the limitations to deduct incurred borrowing costs. ${ }^{97}$ However, the ATAD does not provide any further guidance on how Member States should exercise their taxing rights in situation where article 4(6) is not implemented. Without carry forward or back, taxpayer would have no possibility to eliminate double taxation under the ATAD in the future tax periods. Therefore, non-deductible borrowing costs in borrower's Member State would still be subject to tax in the Member State of a creditor, causing thereby economic double taxation. ${ }^{98}$

Furthermore, even when article 4(6) of the ATAD would be implemented, there would be no certainty that taxpayer would ever be in a position to use the amounts carried forward to the following tax periods. ${ }^{99}$ Taxpayer may never realize enough profit to benefit from the unused interest capacity or exceeding borrowing costs carried forward.

As a consequence of limitation on deductibility of borrowing costs, the taxable base of a borrower is increased irrespective of taxation of the same interest income in the hands of a creditor. Such double tax burden resembles more to economic double taxation than juridical since the same item of income is subject to tax in the hands of different taxpayers - first in the hands of a borrower by reason of nondeductibility and simultaneously in the hands of the creditor as interest income. However, on the side of a borrower, tax is not imposed on the interest income and it is rather the non-deductible borrowing cost of a taxpayer which is subject to corporate taxation. Thus, aforesaid double taxation should not be classified as an economic double taxation resulting from the successive taxation of income intrinsic to classical corporate tax system. Instead, the economic double taxation caused by the interest deduction limitation rule has its origin in a qualification conflict. ${ }^{100}$ In the hands of one taxpayer it is deemed to be non-deductible cost being part of taxpayer's tax base and in the hands of another taxpayer, pursuant to the domestic legislation of that Member State, it qualifies as a taxable interest income. In both Member States, the item of income is subject to corporate income tax according to the legislation of respective Member State.

Moreover, since the rule on limiting the deductibility of borrowing costs in the ATAD apply also in wholly domestic situations where both the borrower and the creditor are located in the same Member State, economic double taxation could also emerge within only one Member State.

Since the ATAD does not oblige Member States to transpose article 4(6), which lays down the principles of carry forward and back, into their domestic legislation, it is evident that the ATAD does

\footnotetext{
${ }^{97}$ The following analysis of interest deduction limitation rules is based on the assumption that borrowing costs are not notional.

${ }^{98}$ OECD. Limiting Base Erosion Involving Interest Deductions and Other Financial Payments, Action 4., op. cit., paragraph 159.

${ }^{99}$ Hoor, O.R., O’Donnell, K., Schmitz Merle, S., EU Commission Releases Draft Directive on BEPS: A Critical Analysis from a Luxembourg Perspective. European Taxation, 2016. Volume 56, No. 5, page 193.

${ }^{100}$ Makhmudova, K., op. cit., page 264.
} 
also not require Member States to eliminate double tax burden created by the interest deduction limitation rule. Even though any kind of double taxation is a hindrance to the internal market, the double taxation in question would not be incompatible with other relevant secondary legislation of the EU such as the Interest and Royalty Directive. This is due to the aim of the Interest and Royalty Directive which is to eliminate only juridical double taxation which would reduce the income of a creditor. Economic double taxation caused by the implementation of ATAD interest deduction limitation rule would therefore be out of the scope of Interest and Royalty Directive and would not restrict the implementation of ATAD. ${ }^{101}$ Thus, even when the rule on limiting the deductibility of borrowing costs of Member States put double tax burden on a taxpayer, Member States would be acting in compliance with the EU law, provided that those rules do not discriminate taxpayers engaged in cross-border activities. Nevertheless, this does not rule out the conflict with EU primary law as regards the proportionality of interest deduction limitation rule. Considering the scope of this thesis, the aspect of proportionality is, however, not examined any further.

In addition to the economic double taxation, interest deduction limitation rules could also trigger juridical double taxation as irrespective of domestic non-deductibility of exceeding borrowing costs, the payment retains its qualification as interest for tax treaty purpose ${ }^{102}$ as well as for the purpose of the Interest and Royalty Directive. ${ }^{103}$ Therefore, the source state (i.e. Member State of a borrower) is entitled to impose a withholding tax on the outbound interest payment in accordance with the OECD MC article 11, provided that the Interest and Royalty Directive is not applicable. The same interest income, however, would most likely be also subject to tax in the state of residence of the creditor which exercises its right to tax the worldwide income of its residents.

\subsection{Controlled Foreign Company Rules}

According to some scholars and the OECD, the use of low tax jurisdictions for shifting profit to companies without genuine economic activity and reducing the tax burden for example by way of low taxation, tax deferral or different characterization of an income ${ }^{104}$ have been used by taxpayers for significant amount of time. In order to combat such practices and achieve capital export neutrality by treating, from the tax point of view, investment income from domestic and outbound investments equally, ${ }^{105}$ states have introduced CFC rules. CFC rules function as anti-avoidance measure ${ }^{106}$ which allow states to extend the application of their domestic legislation beyond their territory ${ }^{107}$ and protect thereby their domestic tax base.

\footnotetext{
${ }^{101}$ Judgement of 21 July 2011, Scheuten Solar Technology, C-397/09, EU:C:2011:499, paragraph 28. Cordewener, A. The Interest and Royalty Directive. European Tax Law. Volume 1 - General Topics and Direct Taxation. 7th Student edition. Edited by Wattel, P., Marres, O., Vermuelen, H. Deventer: Wolters Kluwer, 2018, page 205-206.

102 Makhmudova, K., op. cit., pages 264 - 265.

${ }^{103}$ Interest and Royalty Directive article 2(a) does not make the term "interest" dependent on domestic deductibility.

${ }^{104}$ De Broe, L. International Tax Planning and Prevention of Abuse. A Study under Domestic Tax Law, Tax Treaties and EC Law in Relation to Conduit and Base Companies. IBFD, Doctorial Series, 2008. Volume 14, pages 53, 55-57.

${ }^{105}$ Chand, V. The Interaction of Domestic Anti-Avoidance Rules with Tax Treaties (with special references to the BEPS project). Tax Policy Series. Edited by Danon, R. Geneva/Zurich, 2018, page 71.

${ }^{106}$ Dahlberg, M., Wiman, B. General Report. The taxation of foreign passive income for groups of companies. IFA Cahiers, Volume 98A, 2013, page 26.

${ }^{107}$ De Broe, L., op. cit., page 125.
} 
Once the foreign entity has been confirmed to be a CFC, states generally use one of the following approaches to attribute the income under CFC rules to the resident shareholder: i) taxation of shareholder on the basis of the fair value of the shares - market value approach; ii) look through approach under which the CFC is disregarded and income is imputed directly to the shareholder on the basis of the fiction that the shareholder earned the income directly; iii) fictitious dividend approach which attributes deemed dividend to the shareholder of CFC irrespective of the actual distribution by the foreign company; or iv) an approach which treats the CFC as legal entity but attributes the income to its shareholder, thereby disregarding the CFC as the recipient of the income. ${ }^{108}$

In the ATAD, all aforementioned approaches are in principle feasible as the ATAD only requires the income to be attributed to the taxpayer, leaving the methods as well as the actual taxation to be decided by the Member States. ${ }^{109}$ Minimum standard for the tax treatment of CFCs are established by the articles 7 and 8 of the ATAD, aiming to re-attribute the undistributed income of low-taxed controlled subsidiaries to parent company in the Member State where the parent company is considered to be a resident for tax purposes. ${ }^{110}$ Those rules are binding even for Member States which already have CFC rules in force. ${ }^{111}$ However, as the scope of the ATAD is limited to taxpayers subject to corporate tax in one or more Member States, ${ }^{112}$ CFC rules in question do not apply in case the shareholder is a natural person.

Furthermore, the scope of CFC rules could be even narrower when recognizing the interpretation suggested by some scholars who argue that in conjunction with the recital 12 of the ATAD, CFC rules laid down in article 7 should apply only in case the parent company of a CFC is a tax resident in EU Member State. ${ }^{113}$ Regardless of the potential limitations on the scope of CFC rules as regards its subjects, the use of the concept of "entity" instead of "company" in article 7 of the ATAD implies that CFC rules in question cover in any case for example trusts and partnerships controlled by an EU resident taxpayer. $^{114}$

In order for the CFC rules stipulated in the ATAD to become applicable, three conditions must be met: i) there must be a CFC; ii) CFC's profits must be subject to low taxation; and iii) CFC must receive so called harmful income. ${ }^{115}$

Pursuant to the article 7 of ATAD, an entity or a permanent establishment is regarded as a CFC when all the following conditions are met: i) the entity or permanent establishment is not subject to tax or its profits are exempted in that Member State; ii) the taxpayer itself or together with associated

\footnotetext{
${ }^{108}$ Rust, A. CFC Legislation and EC Law. INTERTAX, 2008. Volume 36, Issue 11, page 493.

${ }^{109}$ Moser, T., Hentschel, S. The Provisions of the EU Anti-Tax Avoidance Directive Regarding Controlled Foreign Company Rules: A Critical Review Based on the Experience with the German CFC Legislation. INTERTAX, 2017. Volume 45, Issue 10, page 620 .

110 ATAD, recital 12.

${ }^{111}$ Van Hulle, G. Current Challenges for EU Controlled Foreign Company Rules. Bulletin for International Taxation, 2017. Volume 71, No. 12, section 2.2.

112 ATAD, article 1.

${ }^{113}$ Moser, T., Hentschel, S., op. cit., page 609 and cited articles.

${ }^{114}$ Rigaut, A. Anti-Tax Avoidance Directive (2016/1164): New EU Policy Horizons. European Taxation, 2016. Volume 56, No 11, section 3.1.

${ }^{115}$ Smit, D., op. cit., page 259.
} 
enterprises ${ }^{116}$ holds more than $50 \%$ of voting rights, capital or is entitled to receive more than $50 \%$ of the profits of the entity; and iii) corporate tax paid on the profits of the entity or permanent establishment is lower than $50 \%{ }^{117}$ of which would have been paid in that Member State. ${ }^{118}$

A carve out is provided for foreign entities and permanent establishments of which the one third or less of the income is considered to be harmful or in case the financial undertakings receive one third or less of their harmful income from transactions with the taxpayer or its associated enterprises. ${ }^{119}$ Furthermore, Member States are entitled to exclude entities and permanent establishments from being regarded as CFCs in case their accounting profits are less than EUR 750,000 with non-trading income no more than EUR 75,000 or their accounting profits do not exceed $10 \%$ of such entity's or permanent establishment's operating costs for the tax period, excluding payments to associated enterprises. ${ }^{120}$

While implementing CFC rules, Member States may choose to apply so-called entity approach (fully fledged CFC rule), transactional based approach (light CFC rule) ${ }^{121}$ or apply both of them simultaneously ${ }^{122}$ to determine the tax base of a CFC. Article 7(2) point (a) of the ATAD establishes for that purpose passive income catalogue and in point (b) principal purpose test. ${ }^{123}$ In both cases, CFC rules of the ATAD target only non-distributed income, ${ }^{124}$ as one of the goals of CFC rules is to prevent taxpayers from deferring their domestic taxation. ${ }^{125}$

Should the CFC carry on substantive economic activity, supported by the staff, equipment, assets and premises, Member States should not deem the income listed in the catalogue to be harmful. However, when the CFC is located outside of the borders of the European Economic Area, Member States are not required to apply the "substantial economic activity test"126 and are permitted to include such income in the tax base of the CFC without further analysis.

The method for calculating the income of a CFC depends on whether the CFC received income listed in the passive income catalogue or the arrangement were considered to be non-genuine with an essential purpose of obtaining a tax advantage. The latter requires Member State to take into consideration the assets, risks as well as significant people functions carried out by the CFC and calculate the income of a CFC in accordance with the arm's length principle. ${ }^{127}$ On the other hand, should the CFC receive

\footnotetext{
${ }^{116}$ As defined in article 2(4) of ATAD.

${ }^{117}$ Rigaut, A., op. cit., section 3.5.

${ }^{118}$ ATAD, article 7(1).

${ }^{119}$ Ibid, article 7(3).

${ }^{120} \mathrm{Ibid}$, article 7(4).

${ }^{121}$ Smit, D., op. cit., page 261.

${ }^{122}$ Ginevra, G., op. cit., page 127.

${ }^{123}$ Moser, T., Hentschel, S., op. cit., page 613.

${ }^{124}$ Smit, D., op. cit., page 262.

${ }^{125}$ Bonn, J. S. CFC Rules and Anti-Tax Avoidance Directive. EC Tax Review, 2017. Volume 26, Issue 3, page 148.

126 ATAD, article 7(2) point (a). Regarding the difference between "substantive economic activity" and "genuine economic activity" as stated by the CJEU, see Bonn, J. S. CFC Rules and Anti-Tax Avoidance Directive., op. cit., page 150; and Danon, R. J. Some Observations on the Carve-Out Clause of Article 7(2)(a) of the ATAD with Regard to Third Countries. The Implementation of Anti-BEPS Rules in the EU: A Comprehensive Study. Edited by Pistone, P., Weber, D. IBFD, 2018, section 17.3.1.

${ }^{127}$ ATAD, article 8(2).
} 
passive income listed in the catalogue, the income included in the tax base of a taxpayer would be calculated in accordance with the rules of taxpayer's Member State. ${ }^{128}$

\subsubsection{Double Taxation from Controlled Foreign Company Rules}

Besides numerous undefined terms in relation to CFC rules in the ATAD which could lead to double tax burden, ${ }^{129}$ the problem of double taxation can also arise from the attribution of CFC income to a taxpayer. Pursuant to the ATAD, the amount of income included in the tax base of the EU resident taxpayer shall be calculated based on its participation in the CFC as defined in article 7(1) point (a). As described above, participation in the CFC can be determined on the basis of voting rights, capital or profit share, covering thereby both the legal and economic control over the entity. ${ }^{130}$ However, the wording of article 7 does not give any guidance on which criteria should be preferred or used as a "tiebreaker" in case the percentage of voting rights, capital or profit share differ, allowing therefore simultaneous application of all three criteria.

Provided that Member States subject CFC income to tax, use of all three criteria could cause a double taxation $^{131}$ as the indirect control referred in article 7(1) point (a) of the ATAD might trigger the application of CFC rules in several Member States at the same time. ${ }^{132}$ This could be the case when the foreign entity is owned by the EU taxpayer through EU tax resident subsidiary and sub-subsidiary which all meet the participation criterion and are deemed to be a CFC in their own Member State. Under such circumstances, several Member States deem the same foreign entity to be a CFC controlled by their tax resident. As a result, all those Member States consider the income of a foreign entity to be attributable to their tax resident and taxable under their CFC rules (Figure 1).

The taxation of the same income on the hands of different taxpayers is caused by the divergences of attribution as both states consider their taxpayer as a recipient of the income. Double tax burden arising from the aforesaid concurrent taxation by various jurisdictions can be categorized as economic double taxation. Since article 8(7) of the ATAD obliges Member State of a taxpayer to provide tax credit only as regards the taxes paid by the entity or permanent establishment, the ATAD does not provide any relief for aforementioned double taxation. ${ }^{133}$ Economic double taxation in question would arise from the CFC tax liability in jurisdictions of the controlling entities and not from the taxes paid by the CFC itself. ${ }^{134}$

\footnotetext{
${ }^{128}$ Ibid, article 8(1).

${ }^{129}$ Govind, S., Zolles, S. The Anti-Tax Avoidance Directive. Introduction to European Tax Law on Direct Taxation, $5^{\text {th }}$ edition. Edited by Lang, M. (Eds), Linde, 2018, page 235.

${ }^{130}$ Ginevra, G., op. cit., page 126.

${ }^{131}$ Moser, T., Hentschel, S., op. cit., pages 611 and 620.

${ }^{132}$ Van Hulle, G., op. cit., section 2.3.

${ }^{133}$ Danon, R. J. Some Observations on the Carve-Out Clause of Article 7(2)(a) of the ATAD with Regard to Third Countries., op. cit., section 17.2.2.

${ }^{134}$ Van Hulle, G., op. cit., section 2.3.
} 


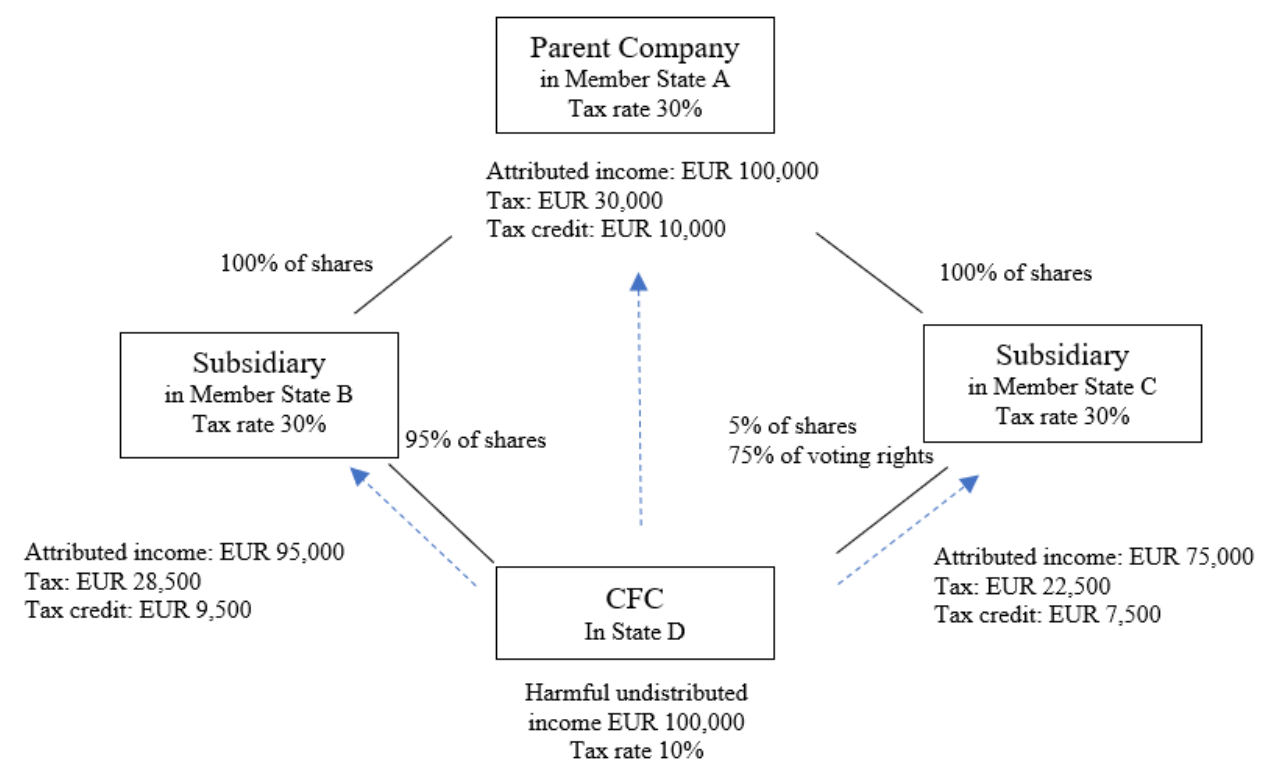

Total tax on CFC income: EUR 54,000, not EUR 30,000.

Figure 1. Author's illustration.

Another cause of double taxation is connected with the calculation of an effective tax rate (Figure $2^{135}$ ). Since the effective tax rate is calculated on a single entity basis, the taxation on the level of controlled subsidiary or sub-subsidiary of the CFC is irrelevant and could trigger double taxation of the income in the hands of the EU parent company. ${ }^{136}$ It would be the situation where the income of a subsidiary of the $\mathrm{CFC}$ has been taxed in accordance with the jurisdiction of subsidiary before passing the income to CFC. Notwithstanding the taxation on the level of any subsidiary or sub-subsidiary, even in case of high effective tax rate, Member State calculating the actual corporate tax paid on the profits of the CFC would not be required to take taxes, paid other than the CFC itself, into account. Thus, de facto highly taxed income of a CFC received through its subsidiary would be deemed to be low-taxed and subject to $\mathrm{CFC}$ regulations, provided that all other conditions are also met. As mentioned above, since the Member States are required to provide relief only in amount of taxes paid by the CFC, there is no obligation under the ATAD to eliminate described economic double taxation. ${ }^{137}$

\footnotetext{
135 The figure is based on the assumption that the Parent-Subsidiary Directive is not applicable as all companies are not located within the EU.

${ }^{136}$ Smit, D., op. cit., page 260. See also Confédération Fiscale Européenne. Opinion Statement FC 3/2016 on the European Commission's proposal for an Anti-Tax Avoidance Directive of 28 January 2016, page 12. Available online http://taxadviserseurope.org/wp-content/uploads/2018/05/CFE-Opinion-Statement-FC-3-2016-on-the-Anti-Tax-AvoidanceDirective.pdf Accessed 08.04.2019.

${ }^{137}$ Ginevra, G., op. cit., page 131.
} 


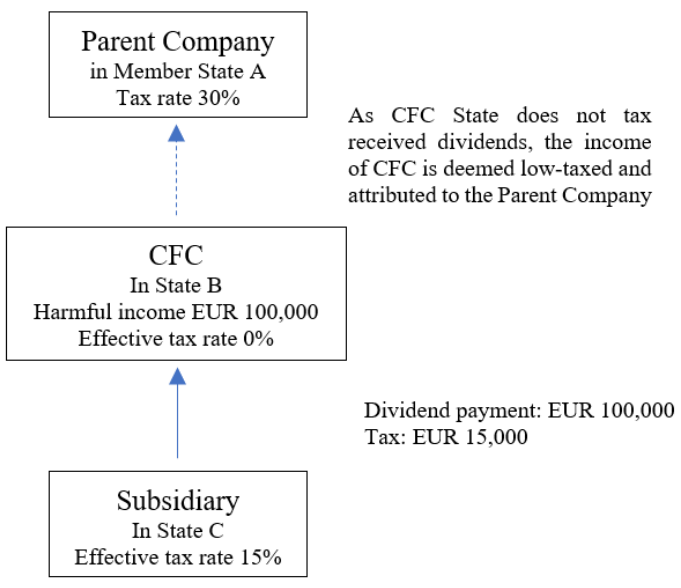

Figure 2. Author's illustration.

In addition to sources of double taxation already mentioned, another potential cause of double taxation is an uncertainty on how the low taxation on the level of CFC resulting from loss carry forward shall be treated by the Member States. ${ }^{138}$ Article $8(1)$ of the ATAD states that the losses of an entity or permanent establishment shall not be deducted from the tax base of a taxpayer but may be carried forward and be taken into account in the future tax periods, provided that it is allowed by the domestic law of a Member State of a taxpayer. However, the impact of such carry forward to effective corporate tax rate has not been regulated. Therefore, due to the loss carry forward from previous tax period, income of a foreign entity or permanent establishment could be subject to lower effective tax rate in that year of assessment. As a result, the aforesaid income could be considered as a low-taxed income by another Member State and be subject to taxation under the CFC rules. Since the ATAD fails to coordinate the impact of loss carry forward to the calculation of an effective tax rate, the ATAD does not provide any instructions how to solve such potential economic double taxation.

Economic double taxation resulting from the actual profit distribution by the CFC after profits have been attributed to the taxpayer and capital gains from the disposal of shares of a CFC, is prevented by the ATAD itself. Under article 8(5) and (6), Member States are required to deduct amounts which have been previously included in the tax base of a taxpayer, pursuant to the CFC rules, from the tax base when calculating the tax obligation on distributed profit. Moreover, Member States are bound to allow indirect credit as article 8(7) obliges Member States to allow deduction of the tax paid by the CFC. ${ }^{139}$ On the other hand, it is debatable whether withholding taxes paid on CFC's dividends are also credited in the Member State of the taxpayer as the tax is actually paid by the taxpayer and not by the CFC. ${ }^{140}$

The problem of dual residency which causes simultaneous application of CFC rules in both states (i.e. by the state of incorporation and by state where the effective place of management is located) is also one source of double taxation. ${ }^{141}$ However, as the dual residency is not a result of implementation of the ATAD (i.e. the ATAD does not determine the residency of a taxpayer), it has not been analyzed any further in this thesis.

\footnotetext{
${ }^{138}$ Moser, T., Hentschel, S., op. cit., page 612 and cited article.

${ }^{139}$ Smit, D., op. cit., page 263.

${ }^{140}$ Moser, T., Hentschel, S., op. cit., page 621; Smit, D., op. cit., page 263.

${ }^{141}$ Van Hulle, G., op. cit., section 2.3.
} 


\section{RELIEF FOR DOUBLE TAXATION RESULTING FROM THE INTEREST DEDUCTION LIMITATION AND CONTROLLED FOREIGN COMPANY RULES OF THE ANTI-TAX AVOIDANCE DIRECTIVE}

\subsection{Relief Under the OECD Model Convention}

The primary aim of the OECD MC is to avoid double taxation of income ${ }^{142}$ as a hindrance to the international trade and investments. ${ }^{143}$ However, as examined in section 2, it is not settled whether the OECD MC should be interpreted as to eliminate both juridical and economic double taxation or should its scope be limited only to juridical double taxation. Regardless of the approach supported, relevant articles for eliminating double taxation in the context of this thesis are articles 23,25 and 9 of the OECD MC.

Tax treaties, by establishing allocation rules, limit the applicability of states' domestic tax legislation and prevent states from exercising their taxing rights. Thereby, double taxation is already unilaterally avoided. ${ }^{144}$ In case the tax treaty does not provide a complete distributive rule and exclude the taxing right of a state of source, the resident state is required to eliminate double taxation by allowing credit or providing an exemption for income taxed by the source state. ${ }^{145}$ Rules for providing tax credit or exempting foreign income are stated in articles $23 \mathrm{~A}$ and 23B of the OECD MC.

Pursuant to the articles 23A and 23B, the OECD MC provides relief of double taxation only when the income has been taxed in accordance with the provisions of OECD MC. ${ }^{146}$ Income is considered to be taxed in accordance with the OECD MC even when the differences in the domestic legislation lead to the allocation of the income under different treaty provision by source and resident state. ${ }^{147}$ That is to say, double taxation resulting from a conflict of qualification due to differences in domestic rules would require resident state to grant relief. There is no obligation for a resident state to provide relief in situations where the double taxation has derived from different interpretation of treaty provisions or facts (i.e. classification conflict). ${ }^{148}$ In such case, the source state is deemed to have taxed the income not in accordance with the tax treaty and article 23 would not be applicable. ${ }^{149}$

To solve double taxation arising from some qualification conflicts, the OECD so called new-approach could be advantageous. The new-approach provides that when the qualification conflict arises, the interpretation of source state should prevail. ${ }^{150}$ Therefore, instead of reaching autonomous qualification, the new-approach obliges state of residence to recognize the qualification of income given by the source state. ${ }^{151}$ However, the new-approach would not solve qualification conflicts in case of complete

\footnotetext{
${ }^{142}$ OECD MC preamble and OECD MC Commentaries. Introduction, paragraph 16.1.

${ }^{143}$ Arnold, B. J., op. cit., page 144.

${ }^{144}$ Rust, A. Klaus Vogel on Double Taxation Conventions, $4^{\text {th }}$ edition, edited by Reimer, E., Rust, A., 2015 . Article 23 at marginal number 3, page 1611 .

${ }^{145} \mathrm{Ibid}$ at marginal number 4, page 1611 .

${ }^{146}$ OECD MC articles 23A(1) and 23B(1).

${ }^{147}$ OECD MC Commentaries on articles 23A and 23B, paragraph 32.3 .

${ }^{148}$ Kienberger, S. Avoidance of Double (Non-)Taxation and Art. 23A and B Paragraph 1 OECD MC. Conflicts of Qualification in Tax Treaty Law. Edited by Burgstaller, E., Haslinger, K. Linde, 2007, page 314.

${ }^{149}$ OECD MC Commentaries on articles 23A and 23B, paragraph 32.5.

${ }^{150}$ OECD MC Commentaries on articles 23A and 23B, paragraph 32.3.

${ }^{151}$ OECD MC Commentaries on articles 23A and 23B, paragraph 32.3. Pleil, C., Schwibinger, S., op. cit., page 447.
} 
distributive rules, as the one prerequisite for the new-approach to come into effect is that article 23 of the OECD MC applies. ${ }^{152}$ In case the article 23 is not applicable, states should apply article 25 of the OECD MC to resolve double taxation under mutual agreement procedure. ${ }^{153}$ Nevertheless, article 25 of the OECD MC does not compel the authorities of contracting states to reach a consensus and eliminate double taxation. ${ }^{154}$

There are three types of mutual agreement procedures under the OECD MC: i) specific case provisions which apply when the taxpayer has not been taxed in accordance with the treaty; ii) interpretative provision to solve difficulties arising from the interpretation and application of a treaty; and iii) legislative provisions to eliminate double taxation in cases not provided for in the treaty. ${ }^{155}$ Under the mutual agreement procedure states may start the process after the taxpayer has presented its case or competent authorities have initiated the procedure by themselves under article $25(3) .{ }^{156}$ In cases of classification conflict, the procedure is most likely to fall under the article 25(3) which is applicable to resolve difficulties arising from the interpretation and application of a tax treaty and eliminate double taxation not provided for in the treaty. On the other hand, double taxation arising from the qualification conflict and not solved by article 23, would fall under the scope of 25(1) and 25(2), unless there is mere violation of domestic law without any connection to a tax treaty. ${ }^{157}$

While for classification conflicts the mutual agreement procedure pursuant to the article 25(3) would be the last resort under the tax treaty, in case of unsolved qualification conflict, article 25(5) requires states to further proceed with the mandatory arbitration process ${ }^{158}$ and eliminate double taxation. This, however, would be the case only when states have included mandatory arbitration clause in their tax treaty, otherwise, states in question would unlikely agree on initiating an arbitration process after being unsuccessful to first reach a mutual agreement. ${ }^{159}$

Besides article 23 and 25 of the OECD MC, article 9 provides relief for specific cases of double taxation. The scope of article 9 is rather limited as it only deals with double taxation resulting from the cross-border profit adjustments between associated parties. ${ }^{160}$ In order to eliminate double taxation caused by a qualification conflict under which the same item of income is subject to tax in the state of source as well as in the state of residence, article 9(2) requires the other state to make a corresponding adjustment and decrease the tax base of a taxpayer in accordance with the primary adjustment. However, the other state has such obligation only when it considers the primary adjustment to be correct in principle and as regards the amount. ${ }^{161}$ Should the states disagree, they should consult each other and

\footnotetext{
${ }^{152}$ Vogel, K. Conflicts of Qualification: The Discussion is not Finished. Bulletin for International Taxation, 2003. Volume 57, No 2, page 43.

${ }_{153}$ OECD MC Commentaries on articles 23A and 23B, paragraph 32.5.

${ }^{154}$ OECD MC Commentaries on article 25, paragraph 37.

155 Jones, J.F.A. et al. The Legal Nature of The Mutual Agreement Procedure Under the OECD Model Convention - I. British Tax Review, 1979. Vol. 1979, Issue 6, pages 334-335.

${ }^{156}$ Ismer, R., op. cit., Article 25 at marginal number 4, page 1780.

${ }^{157}$ Ibid at marginal number 27, page 1788 .

${ }^{158}$ The wording of article 25(5) of the OECD MC refers only to paragraphs 1 and 2 of article 25 and not to paragraph 3.

${ }^{159}$ Weninger, P. The Role of Arbitration in Resolving Qualification Conflicts under Tax Treaties. Conflicts of Qualification in Tax Treaty Law. Edited by Burgstaller, E., Haslinger, K. Linde, 2007, page 357.

${ }^{160}$ OECD MC Commentaries on article 9, paragraph 5.

${ }^{161}$ OECD MC Commentaries on article 9, paragraph 6.
} 
if necessary, start a mutual agreement procedure to endeavor to solve the double taxation. ${ }^{162}$ The actual elimination of double taxation is not required by the OECD MC nor is state required to relieve any double taxation from non-arm's length adjustments. ${ }^{163}$

Based on the aforementioned, in order to eliminate the double taxation resulting from the implementation of the ATAD under the OECD MC, such double taxation should have connection with the OECD MC distributive rules - the income must be taxed in accordance with the OECD MC or by violating the provisions of the OECD MC in order to fall under article 25.

\subsubsection{Interest Deduction Limitation Rule}

Taking into consideration that the interest deduction limitation rule allow a Member State to deny the deduction of exceeding borrowing costs and increase the taxable base of a taxpayer, it could be concluded that by limiting deductible borrowing costs, this Member State simultaneously adjusts the interest rate of a loan ${ }^{164}$ and thereby the profits attributable to its tax resident. In case a Member State denies deduction of exceeding borrowing costs arising from a cross-border loan granted between associated parties, the adjustment falls within the scope of article 9 of OECD MC.

The OECD expressed its position regarding the applicability of article 9 to thin capitalization rules already in 1986. ${ }^{165}$ According to the OECD, article 9 is not only relevant to determine whether the interest rate is an arm's length rate but also whether a prima facie loan can be regarded as a loan. ${ }^{166}$ The latter function of article 9 is, however, disputable and not supported by all scholars. ${ }^{167}$

As the interest deduction limitation rule of the ATAD does not foresee the recharacterization of a loan in case of exceeding borrowing costs, there is no doubt about the applicability of article 9 of OECD MC. Compared to the other articles in OECD MC, article 9 is an exception as it does not allocate taxing rights between states but addresses the problem of economic double taxation ${ }^{168}$ by introducing a mechanism of corresponding adjustment. ${ }^{169}$ Thus, in order to avoid economic double taxation from qualification conflict which arises when the Member State of a borrower denies the deduction of borrowing costs and the Member State of a creditor subjects the interest income to tax, the Member State of the creditor should make the corresponding adjustment and reduce the taxable profit attributable to its tax resident (i.e. creditor). However, the corresponding adjustment is not made automatically. The Member State of the creditor is obliged to make the corresponding adjustment only when it agrees with the primary adjustment in principle and as regards the amount. ${ }^{170}$ Should the Member State of the creditor disagree with the primary adjustment, there is no obligation to adjust the tax base of the taxpayer and provide relief under article 9(2). Moreover, increasing the tax base of a

\footnotetext{
${ }^{162}$ Ibid, paragraph 11 and on article 25, paragraph 10.

${ }^{163}$ Kofler, G. Klaus Vogel on Double Taxation Conventions, $4{ }^{\text {th }}$ edition, edited by Reimer, E., Rust, A., 2015. Article 9 at marginal number 7, page 597.

${ }^{164}$ Ibid at marginal number 103, page 669.

${ }^{165}$ OECD. Thin Capitalisation (adopted by the OECD Council on 26 November 1986). Reproduced in the Volume II of the full version of the OECD Model Tax Convention at page R(4)-1, paragraphs 27-32.

${ }^{166}$ OECD MC Commentaries on article 9, paragraph 3.

${ }^{167}$ Kofler, G., op. cit., Article 9 at marginal number 103, page 669 and 670.

${ }^{168}$ Lang, M. Introduction to the Law of Double Taxation Conventions (Second Revised Edition). IBFD, 2013 , paragraph 475.

${ }^{169}$ OECD MC Commentaries on article 9, paragraph 5.

${ }^{170}$ OECD MC Commentaries on article 9, paragraph 6.
} 
resident taxpayer is not conflicting with the OECD MC as the OECD MC focuses only on the taxation of the recipient of the income and not on the situation of a payor. ${ }^{171}$

Provided that the double taxation is not solved under the article 9(2), Member States should endeavor to solve the problem of double taxation through mutual agreement procedure. ${ }^{172}$ However, mutual agreement procedure would not oblige Member States to effectively eliminate double taxation, unless Member States have agreed on mandatory arbitration. Nevertheless, neither of the aforementioned tools for providing relief for double taxation would be available in case the interest deduction of a domestic loan or loan granted between unrelated parties is denied.

In addition to aforesaid economic double taxation, interest deduction limitation rule can also cause juridical double taxation. As the non-deductibility of borrowing costs in a Member State do not affect its categorization for tax treaty purpose, ${ }^{173}$ the Member State of a borrower as a source state is entitled to tax the outbound interest payment in accordance with the article 11 of OECD MC and levy withholding tax. The same interest income, however, would most likely be also taxed by the Member State of a creditor as a resident state. Nevertheless, the aforesaid juridical double taxation would be solved under the OECD MC since the state of residence would be obliged to exempt the foreign income of its resident (i.e. the creditor) or credit the tax withheld in source state in accordance with the article 23 of OECD MC, provided that the double taxation is not notional. ${ }^{174}$

\subsubsection{Controlled Foreign Company Rules}

It has been agreed that the CFC rules do not conflict with tax treaties as they do not limit states' right to tax their own residents, on the contrary, they permit states to tax their residents on income attributable to them based on their participation in foreign entities. ${ }^{175}$ Furthermore, CFC rules, under which the income of a foreign entity is included in the tax base of a resident taxpayer, do not affect the allocation on taxing rights between states but only change the moment at which the resident state is entitled to exercise its taxing right. ${ }^{176}$ Thus, as CFC rules function as an income attribution rules, they are not addressed by tax treaties and it depends only on domestic legislation to whom the income is attributed. ${ }^{177}$

Since the CFC rules generally do not trigger simultaneous taxation of income by the state of residence and state of source on the hands of the same taxpayer but tax the profits of CFC on the hands of CFC as well as on the hands of its shareholder, CFC rules can trigger economic double taxation to the extent the state of shareholder does not provide any relief. ${ }^{178}$ Based on the analysis in section 3.2.1., it can be

\footnotetext{
${ }^{171}$ Makhmudova, K., op. cit., page 264.

172 OECD. Thin Capitalisation., op. cit., paragraph 67.

${ }^{173}$ Makhmudova, K., op. cit., pages 264 - 265.

${ }^{174}$ Lang, M. 2008 OECD Model: Conflicts of Qualification and Double Non-Taxation., op. cit., page 205.

${ }^{175}$ OECD MC Commentaries on article 1, paragraph 81.

${ }^{176}$ Blum, D. W. Controlled Foreign Companies: Selected Policy Issues - or the Missing Elements of BEPS Action 3 and the AntiTax Avoidance Directive. INTERTAX, 2018. Volume 46, Issue 4, page 309.

${ }^{177}$ Rust, A. National Report Germany. CFC Legislation. Domestic Provisions, Tax Treaties and EC Law. Edited by Lang, M. et al. Linde, 2004, page 267.

${ }^{178}$ De Broe, L., op. cit., page 580.
} 
concluded that also CFC rules in the ATAD cause economic double taxation to the extent Member State of a shareholder (i.e. EU taxpayer) does not exempt the foreign income or provide credit.

In order to analyze whether the OECD MC provides any relief for economic double taxation resulting from the CFC rules, it is first necessary to agree on the approach taken. As examined in the section 2.3., the OECD MC could be interpreted as eliminating in addition to juridical double taxation also economic double taxation, other than resulting from the classical corporate tax system. Supporting the latter interpretation, the following analysis focuses on the economic double taxation arising from the implementation of CFC rules of the ATAD for which the ATAD provides no relief.

Pursuant to the commentaries on articles 23A and 23B, it could be argued that the position of the OECD is that in case the state of residence of a shareholder attributes the income of a CFC to its resident shareholder, it is also obliged to take into consideration the tax paid by the CFC and provide the shareholder with tax credit, to the extent the tax was paid in accordance with the tax treaty. ${ }^{179}$ In other words, as the corporate status of a CFC is ignored to determine the taxable profit of a shareholder, it should likewise be ignored for the purposes of providing foreign tax credit. ${ }^{180}$

As the domestic CFC rules are not inconsistent with the OECD MC, they do not affect the distributive rules and states' right to tax the income attributed to the shareholder pursuant to article 7, 10 or any other special distribution rule. ${ }^{181}$ Nevertheless, it has been discussed under which provisions and to what extent states should eliminate double taxation triggered by the CFC rules. Prevailing, so-called OECD approach obliges the state of residence of a shareholder to grant tax credit under article 23B without distinguishing the type of income earned by the CFC, shareholder's participation in the business activity or where the income was derived. ${ }^{182}$ Another approach, presented by professor Alexander Rust, suggests that the state of residence should generally grant an indirect tax credit for taxes paid by the CFC. However, there is no obligation to provide indirect tax credit when the CFC only derives passive income. By receiving only passive income, the CFC does not create a permanent establishment for its shareholders and therefore, the CFC state as source state would have not been entitled to tax the shareholders had such passive income been attributed to the shareholders directly. ${ }^{183}$ Thus, there is no taxation in accordance with the tax treaty in the source state which would trigger the application of article $23 \mathrm{~B}$ of the OECD MC by state of residence of the shareholder.

Based on the analysis in section 3.2.1., double taxation deriving from the implementation of CFC rules of the ATAD can arise from: i) participation criteria; ii) effective tax rate; and iii) loss carry forward. Following the so-called OECD approach, the resident state of a shareholder shall provide foreign tax credit notwithstanding the type of income CFC received, shareholder's involvement in the business activities or from which state the income was derived. ${ }^{184}$ Depending on the attribution method Member State chooses to apply (e.g. look through approach, deemed dividend approach ${ }^{185}$ ), the income of a

\footnotetext{
${ }^{179}$ OECD MC Commentaries on articles 23A and B, paragraph 69.2.

${ }^{180}$ Kuźniacki, B., op. cit., page 768.

${ }^{181}$ Rust, A. National Report Germany., op. cit., page 267.

${ }^{182}$ Kuźniacki, B., op. cit., page 769.

${ }^{183}$ Rust, A. National Report Germany., op. cit., page 270.

${ }^{184}$ Kuźniacki, B., op. cit., page 769.

${ }^{185}$ For more detailed overview see section 3.2.
} 
shareholder of a CFC would most likely be taxed pursuant to article 7, 10 or 21 of the OECD MC and once taxed by the source state in accordance with the tax treaty, the resident state of the shareholder, in principle, is obliged to provide relief for double taxation. However, the state of residence would be required to provide relief under article 23 of the OECD MC only as regards the taxes paid by the CFC and not by subsidiaries or sub-subsidiaries of the taxpayer or CFC. Furthermore, as Member State would credit only the actual tax paid by the CFC, the impact of loss carry forward on the calculation of an effective tax rate would not be taken into consideration. Therefore, OECD MC article 23 would not provide any relief for double taxation in question resulting from the CFC rules of the ATAD.

Furthermore, article 25 of the OECD MC would also not solve the double taxation in question as the double taxation would arise from the domestic CFC rules which are not addressed by the tax treaty. Therefore, there is no taxation not in accordance with the tax treaty in case of which the article 25 of OECD MC would become applicable.

Should one support another approach mentioned above, there would be no requirement to provide any tax credit as regards the income listed in article 7(2) point (a) of the ATAD. In case article 7(2) point (b) of the ATAD is applied, the foreign tax credit would be denied only when CFC receives passive income which would not have granted the source state a taxing right would it have been derived directly by the shareholders of CFC. Nevertheless, even in case of other than passive income, the state of residence would be obliged to credit only taxes paid by the CFC, not by subsidiaries or sub-subsidiaries of the taxpayer or CFC. Thus, also the application of the non-OECD approach could lead to situation where the state is not obliged to eliminate the double taxation.

The aforementioned problem of double taxation could be solved when the state of residence of EU parent taxpayer as well as Member States of its subsidiaries and sub-subsidiaries would apply the exemption method. However, by applying the exemption method, the CFC rules become meaningless as the income would be tax exempt irrespective of the taxation at the level of CFC or its subsidiaries.

\subsection{Relief Under European Union Legislation}

Pursuant to the preamble of the ATAD, its main purpose is to combat abusive practices in EU and ensure that tax is paid where profits are generated without undermining the functioning of the internal market through double taxation. ${ }^{186}$ Regardless of the aim of avoiding creating double tax burden to taxpayers, the ATAD does not oblige Member States to effectively eliminate aforesaid burden. Therefore, taxpayers are compelled to seek the elimination of double taxation elsewhere.

Irrespective of the lack of general provision in EU legislation requiring Member States to eliminate double taxation, ${ }^{187}$ the CJEU has confirmed the elimination of double taxation to be an aim of EU law. ${ }^{188}$ However, since the EU legislation does not define taxing jurisdiction, it also does not determine

\footnotetext{
186 ATAD, recital 1 and 5.

${ }^{187}$ Helminen, M. The Principle of Elimination of Double Taxation under EU Law - Does it Exist? Principles of Law: Function, Status and Impact in EU Tax Law. Edited by Cécile Brokelind. IBFD, 2014, Chapter 17.2. and case law cited.

${ }^{188}$ For example judgement of 12 May 1998, Gilly, C-336/96, EU:C:1998:221, paragraph 15.
} 
which Member State has the right to tax the income and which one should be responsible for providing a relief from double taxation. ${ }^{189}$

Up to now the CJEU has applied EU primary law to provide relief for double taxation in cases where economic double taxation results from discriminatory domestic legislation. ${ }^{190}$ Juridical double taxation resulting from disparities or parallel exercise of taxing rights has generally ${ }^{191}$ been found to fall outside of the scope of Treaty of Functioning of European Union (TFEU) and despite of being a restriction of free movement, compatible with EU primary law. ${ }^{192}$

Based on the analysis in section 3.1.1., it could be concluded that double taxation resulting from the interest deduction limitation and CFC rules of the ATAD could be characterized as economic as well as juridical double taxation. Since the EU primary law does generally not provide any relief for juridical double taxation resulting from the parallel exercise of taxing rights of Member States or from disparities, it is apparent that EU primary law would not eliminate juridical double taxation caused by the implementation of the ATAD. As regards the economic double taxation, EU primary law would oblige Member State to eliminate double tax burden provided that the domestic legislation of a Member State would disadvantage a taxpayer engaged in cross-border activities.

In case EU primary law does not provide any relief for double taxation, the taxpayer may turn to the Arbitration Convention ${ }^{193}$ and the Dispute Resolution Directive to seek relief of double taxation. However, considering that the scope of the Arbitration Convention is limited to disputes related to profit attribution to permanent establishment and transfer pricing adjustments between Member States, its application to resolve double taxation resulting from the ATAD could be limited. Nonetheless, it has been pointed out that the Arbitration Convention could provide relief when application of the provisions based on the ATAD lead to non-arm's length conditions imposed on transactions between related parties. $^{194}$

Since there is no hierarchy between the Arbitration Convention and Dispute Resolution Directive, the taxpayer may choose from 1 July 2019 which one to apply. ${ }^{195}$ Unlike the Arbitration Convention, the scope of Dispute Resolution Directive is not limited to transfer pricing adjustments and profit attribution disputes. The Dispute Resolution Directive would be applicable to solve any dispute arising from "the interpretation and application of agreements and conventions that provide for the elimination

\footnotetext{
${ }^{189}$ Wattel, J., Conceptual Background of the CJEU Case Law in Direct Tax Matters., op. cit., page 316.

${ }^{190}$ For example, judgement of 13 November 2012, Test Claimants in the FII Group Litigation, C-35/11, EU:C:2012:707, paragraph 38 and case law cited.

${ }^{191}$ The CJEU have found juridical double taxation resulting from the discriminatory withholding taxes to fall within the scope of TFEU, see for example judgement of 8 November 2007, Amurta, C-379/05, EU:C:2007:655.

${ }^{192}$ Wattel, J., Conceptual Background of the CJEU Case Law in Direct Tax Matters., op. cit., page 316.

${ }^{193}$ Arbitration Convention is not part of EU legislation; however, it is part of acquis communitaire and is therefore analyzed under this section of the thesis. Regarding legal status of Arbitration Convention, see Hinnekens, L. The Uneasy Case and Fate of Article 293 Second Indent EC. INTERTAX, 2009. Volume 37, Issue 11, page 604.

${ }^{194}$ De Graaf, A., Visser, K-J., ATA Directive: Some Observations Regarding Formal Aspects. EC Tax Review, 2016. Volume 25, Issue 4, page 208.

195 Pistone, B. The Settlement of Cross-Border Tax Disputes in the European Union. European Tax Law. Volume 1 - General Topics and Direct Taxation. 7th Student edition. Edited by Wattel, P., Marres, O., Vermuelen, H. Deventer: Wolters Kluwer, 2018, page 178 .
} 
of double taxation of income and, where applicable, capital". ${ }^{196}$ Assuming, thus, that Member States have concluded a tax treaty. ${ }^{197}$

Double taxation, solved by the Dispute Resolution Directive, is defined as imposition of taxes by two or more Member States in respect of the same income or capital, ${ }^{198}$ adopting thereby a broad concept and including both economic as well as juridical double taxation. ${ }^{199}$ Despite the rather broad scope of the Dispute Resolution Directive and its aim to effectively resolve disputes leading to double taxation, ${ }^{200}$ it does not require Member States explicitly to achieve such outcome. ${ }^{201}$ Furthermore, Member States would not be obliged to provide any relief of double taxation during the settlement period and the taxpayer would be liable to bear its own costs related to the settlement, ${ }^{202}$ creating thereby significant financial burden.

Pursuant to the wording of article 1 of the Dispute Resolution Directive, all disputes arising from tax treaties concluded between Member States fall within the scope of the Dispute Resolution Directive. ${ }^{203}$ However, it is questionable whether double taxation resulting from the ATAD and disputes on such double taxation would be resolved under the Dispute Resolution Directive.

First, the ATAD is adopted based on the article 115 of TFEU as a directive and would be binding to the Member States as to the result to be achieved. ${ }^{204}$ By applying literal interpretation and using the ordinary meaning of "agreement" and "convention", both terms could be defined as an arrangement between parties. ${ }^{205} \mathrm{~A}$ directive or its transposition into domestic legislation, however, could not be understood as an "agreement" or "convention". Furthermore, taking into consideration the context of the Dispute Resolution Directive, it is evident that only arrangements like tax treaties and similar agreements between Member States could be understood as agreements and conventions covered by the Dispute Resolution Directive. This approach is also supported by the recital 2 of Dispute Resolution Directive and the preparatory work of Dispute Resolution Directive ${ }^{206}$ which both explicitly limit the scope of Dispute Resolution Directive with double taxation agreements between Member States and

\footnotetext{
${ }^{196}$ Dispute Resolution Directive, article 1.

${ }^{197}$ Pit, H. M. Dispute Resolution in the EU. The EU Arbitration Convention and the Dispute Resolution Directive. IBFD, Doctorial Series, 2018. Volume 42, page 1242.

198 Dispute Resolution Directive, article 2(1)(c).

${ }^{199}$ Govind, S., Turcan, L. The Changing Contours of Dispute Resolution in the International Tax World: Comparing the OECD Multilateral Instrument and the Proposed EU Arbitration Directive. Bulletin for International Taxation, 2017. Volume 71, No. 3/4, section 3.2.

${ }^{200}$ Dispute Resolution Directive, recital 2.

${ }^{201}$ Pistone, B., op. cit., page 179.

202 Dispute Resolution Directive, article 12(1).

${ }^{203}$ Govind, S. The New Face of International Tax Dispute Resolution: Comparing the OECD Multilateral Instrument with the EU Dispute Resolution Directive. EC Tax Review, 2018. Volume 27, Issue 6, page 310.

204 TFEU, article 288.

205 Oxford dictionary provides the following definitions: agreement - "a negotiated and typically legally binding arrangement between parties as to a course of action"; convention - "an agreement between states covering particular matters, especially one less formal than a treaty". Available online - https://en.oxforddictionaries.com/. Accessed 20.03.2019.

206 Council of the European Union. Note on Dispute Resolution Mechanisms - Proposal for a Council Directive on Double Taxation Dispute Resolution Mechanisms in the European Union, General approach. 12 May 2017, 9011/17, paragraph 8.
} 
Arbitration Convention. Also disputes arising from the MLI have been considered to fall under the scope of Dispute Resolution Directive. ${ }^{207}$

Therefore, disputes of double taxation arising from the implementation of ATAD would not directly fall under the scope of the Dispute Resolution Directive. Thus, the aforesaid problem of double taxation could be solved by the Dispute Resolution Directive provided that the exercise of taxing rights under the ATAD would comply with a tax treaty signed between Member States and the double taxation could be derived from such treaty. On the other hand, double taxation resulting from the implementation of ATAD could fall under the scope of Dispute Resolution Directive in case Member State has implemented the Dispute Resolution Directive more beneficially for taxpayers by extending its scope also to double taxation other than arising from agreements and conventions. ${ }^{208}$

\subsubsection{Interest Deduction Limitation Rule}

Based on the analysis in section 3.1.1., limitation on deductibility of borrowing costs could trigger economic double taxation resulting from the qualification conflict in case the deductibility of borrowing costs in one Member State is denied and received interest payment in another Member State is treated as taxable income. The ATAD recommends Member States to implement carry forward and carry back rules to eliminate double taxation, however, Member States are not obliged to follow the suggestion. Therefore, the economic double taxation arising from the implementation of interest deduction limitation rule is likely to occur.

Taking into consideration the wording of recital 7 and article 4 of the ATAD, it is evident that the application of interest deduction limitation rule is not limited to cross-border situations. On the contrary, deduction of exceeding borrowing costs would be limited equally in domestic and cross-border situations without any discrimination based on the source of a debt or location of a taxpayer. ${ }^{209}$ Since there would be no discrimination between cross-border and domestic treatment of interest deduction limitation, the interest deduction limitation rule based on the article 4 of ATAD would comply with the article 49 of TFEU. Therefore, it is unlikely that the CJEU would find EU primary law applicable to eliminate economic double taxation resulting from the limitation on deductibility of borrowing costs introduced by Member States while implementing the ATAD.

However, double taxation arising from the interest deduction limitation rule would fall into the scope of the Arbitration Convention to the extent the deduction of borrowing costs is denied on cross-border loan granted between associated parties. Since the interest deduction limitation rule of the ATAD does not recharacterize the loan into equity but only limit the amount of deductible interest, this rule, in principle, adjust the interest rate applied between associated parties. Pursuant to the article 1 of the Arbitration Convention, disputes regarding the adjustments of profits of associated parties in different Member States are in the scope of the Arbitration Convention. The applicability of the Arbitration

\footnotetext{
${ }^{207}$ Govind, S., Turcan, L. Cross-Border Tax Dispute Resolution in the 21st century: A Comparative Study of Existing Bilateral and Multilateral Remedies. Derivatives \& Financial Instruments, 2017. Volume 19, No. 5, section 2.2.2.

${ }^{208}$ Debelva, F., Luts, J. The European Commission's Proposal for Double Taxation Dispute Resolution: Turning the Tide? Bulletin for International Taxation, 2017. Volume 71, No. 5, section 3.1.2.

${ }^{209}$ Bizioli, G. Taking EU Fundamental Freedoms Seriously: Does the Anti-Tax Avoidance Directive Take Precedence over the Single Market? EC Tax Review, 2017. Volume 26, Issue 3, page 173.
} 
Convention to thin capitalization rules has been confirmed also by the Commission ${ }^{210}$ as well as by the Council. $^{211}$

Therefore, in case of cross-border loan between associated parties, the taxpayer may rely on the Arbitration Convention to force Member States to eliminate the double taxation resulting from the implementation of the interest deduction limitation rule of the ATAD. ${ }^{212}$ However, as the Arbitration Convention only covers situations between associated parties within the EU, double taxation resulting from the non-deductibility of borrowing costs of domestic loans, loans granted between non-related parties or with one party outside of the EU, falls outside the scope of the Arbitration Convention.

As analyzed in section 4.2., the Dispute Resolution Directive would provide relief for aforesaid double taxation only when the dispute would derive from the interpretation or application of a tax treaty or when Member States have expanded the scope of the Dispute Resolution Directive.

Based on the analysis in section 4.1.1., it can be concluded that the economic double taxation in question derives from the interpretation and application of article 9 of the OECD MC as Member State denying the deduction of exceeding borrowing costs thereby also adjusts the profit attributable to its tax resident. As article 9(2) foresees making of corresponding adjustment in case the other Member State agrees with the primary adjustment, article 9(2) of the OECD MC avoids double taxation arising from the interest deduction limitation rule. Nevertheless, when the other Member State disagrees with the adjustment, double taxation would not be avoided, and the taxpayer would be entitled to submit a complaint and start proceedings to eliminate double taxation under the Dispute Resolution Directive. ${ }^{213}$

Similarly to the Arbitration Convention, the Dispute Resolution Directive is also applicable only in situations concerning the non-deductibility of borrowing costs of a cross-border loan granted between associated parties as the scope of the Dispute Resolution Directive is limited to disputes between Member States. ${ }^{214}$ Hence, without the recharacterization of the loan, only article 9 of OECD MC would be applicable. Therefore, double taxation arising from the interest deduction limitation in connection to a domestic loan, a loan between non-related parties or with one party outside of the EU, no relief is provided under the Arbitration Convention nor the Dispute Resolution Directive.

Some scholars see a solution for economic double taxation arising from the interest deduction limitation rule in implementing adjustment mechanism under which the Member State of a creditor would adjust the profits in amount of exceeding interest income in case the Member State of a borrower limits the interest deduction. ${ }^{215}$ In theory, the idea could resolve the problem of double taxation, even in case of non-related parties. Nevertheless, in practice it would most likely face in addition to the increased

\footnotetext{
${ }^{210}$ Commission of The European Communities. Communication from The Commission To The Council, The European Parliament And The European Economic And Social Committee on the work of the EU Joint Transfer Pricing Forum in the period March 2007 to March 2009 and a related proposal for a revised Code of Conduct for the effective implementation of the Arbitration Convention (90/436/EEC of 23 July 1990). 14.9.2009. COM(2009) 472 final, paragraphs 18 and 20.

${ }^{211}$ Revised Code of Conduct for the effective implementation of the Convention on the elimination of double taxation in connection with the adjustment of profits of associated enterprises. Official Journal C 322, 30.12.2009, pages 1-10, paragraph 1.2.

212 Pursuant to the article 7(1) and article 14, states are obliged to eliminate double taxation.

${ }^{213}$ Dispute Resolution Directive, article 3.

${ }^{214}$ Ibid, article 1.

${ }^{215}$ Lobita, J. C., op. cit., page 62.
} 
administrative burden the same difficulties as abovementioned transfer pricing adjustments under the article 9 of OECD MC - Member States would often not agree on the amount which needs to be adjusted. Mainly because the Member State required to make downwards adjustment of a tax base of its resident would lose tax revenue and would prefer not to make any adjustments. Since the allocation of a tax base fall under the jurisdiction of Member States, the EU law cannot require Member States to adjust the tax base of their residents in accordance with tax consequences in another Member State. ${ }^{216}$ Therefore, the aforementioned solution would eliminate economic double taxation only when Member States would voluntarily cooperate and agree on the adjusted amount, resembling thereby to article $9(2)$ of the OECD MC.

In addition to economic double taxation, interest deduction limitation rule of the ATAD could also result in juridical double taxation. A qualification conflict leading to juridical double taxation arises when the income retains its categorization as interest income for tax treaty purpose $\mathrm{e}^{217}$ and permits thereby the state of source to impose, in principle, a withholding tax pursuant to the article 11 of OECD MC. The same income, however, would most likely be also subject to tax in the state of residence which imposes taxes on the worldwide income of its residents.

Regardless of the limited impact on economic double taxation as examined in section 3.1.1., the Interest and Royalty Directive avoids, to certain extent, potential juridical double taxation arising from the implementation of interest deduction limitation rule. The Interest and Royalty Directive restrains, under certain conditions, the source state from imposing taxes, such as a domestic withholding tax, on interest payments made between associated companies or permanent establishments of different Member States. Nevertheless, in case the interest payment does not fall into the scope of Interest and Royalty Directive, the source state is not prohibited to subject the interest payment to tax in accordance with its domestic legislation and the tax treaty concluded between those Member States.

Furthermore, as the same income would most likely be subject to tax in the state of residence of creditor, the problem of double taxation emerges. In case the OECD MC does not provide a relief, the taxpayer would be entitled to start dispute settlement under the Dispute Resolution Directive as such disagreement would fall within the scope of the directive. However, due to its limited scope, the Arbitration Convention would not be applicable.

\subsubsection{Controlled Foreign Company Rules}

As examined in section 3.2.1., the implementation of CFC rules of the ATAD could cause economic double taxation when Member States attribute the income of a CFC to their resident taxpayers, regardless of taxation of the same income in other than CFC state. According to the ATAD, Member States are required to eliminate economic double taxation caused by the actual distribution of dividends of CFC and the disposal of shares of CFC. However, pursuant to the ATAD, Member States are not required to provide relief for any other double taxation resulting from the implementation of CFC rules.

\footnotetext{
${ }^{216}$ See for example judgement of 10 June 2015, X AB, C-686/13, EU:C:2015:375, paragraph 33.

${ }^{217}$ Makhmudova, K., op. cit., pages 264 - 265.
} 
As described above, under the EU law a taxpayer may seek a solution for the problem of double taxation from primary law, the Arbitration Convention and Dispute Resolution Directive. Following the interpretation of the case law of CJEU, CFC rules are in compliance with EU primary law when i) CFC rules are applied only in case the $\mathrm{CFC}$ did not engage in genuine economic activity (carve-out); and ii) CFC rules apply equally to domestic and cross-border situations. ${ }^{218}$

Based on the wording of CFC rules in the ATAD, it appears that CFC rules compel Member States to introduce a carve-out for companies with substantial economic activity. However, as CFC rules are not intended to be applied in domestic situations, they could be seen as discriminating taxpayers engaged in cross-border activities. On the other hand, some scholars have claimed that the CFC rules could be seen as merely allocating taxing rights and having therefore no interference with fundamental freedoms. ${ }^{219}$ It has also been discussed that the CJEU would probably not assess the CFC rules of the ATAD in the light of EU primary law, instead, the CJEU would conduct its analysis based on the ATAD itself. $^{220}$ Regardless of the approach taken by the CJEU, CFC rules discriminating cross-border activities could be justified on the grounds of overriding reasons of public interests ${ }^{221}$ and be thereby compatible with EU primary law. ${ }^{22}$ Therefore, it is unlikely that the economic double taxation resulting from the implementation of CFC rules would be solved under the EU primary law. Nevertheless, this conclusion would be debatable in case the income of a CFC is not subject to low taxation but there is no taxation in the state of CFC. Under such circumstances, the application of CFC rules would not result in double taxation and analysis regarding the relief under the EU primary law would not be necessary.

The double taxation in question would be consistent also with relevant EU secondary legislation namely the Parent-Subsidiary Directive. It has been discussed that the scope of CFC rules could be limited by the Parent-Subsidiary Directive ${ }^{223}$ as the Parent-Subsidiary Directive prohibits taxation of dividends derived from direct investment within EU, even in case of deemed dividends. ${ }^{224}$ Thus, in case the CFC income would be qualified as profit distribution under the Parent-Subsidiary Directive, the Member State of the shareholder (i.e. parent company) would be required to exempt such distribution or provide tax credit. This, however, is in accordance with the article 8(5) of ATAD which obliges Member States to provide indirect tax credit. Nevertheless, neither the ATAD nor the Parent-Subsidiary Directive prohibit or provide relief for the economic double taxation arising from i) participation criteria; ii) effective tax rate; or iii) loss carry forward.

Taking into consideration the limited scope of the Arbitration Convention, it is also doubtful whether the double taxation resulting from the application of domestic CFC rules is covered by the Arbitration

\footnotetext{
${ }^{218}$ Ginevra, G., op. cit., page 129.

${ }^{219}$ Dourado, A. P. The EU Anti Tax Avoidance Package: Moving Ahead of BEPS?, op. cit., page 441.

${ }^{220}$ Ginevra, G., op. cit., page 129. Also, Wattel, P., Brokelind, C. Free Movement and Tax Base Integrity. European Tax Law. Volume 1 - General Topics and Direct Taxation. 7th Student edition. Edited by Wattel, P., Marres, O., Vermuelen, H. Deventer: Wolters Kluwer, 2018, page 342-343.

${ }^{221}$ Judgement of 12 September 2006, Cadbury Schweppes, C-196/04, EU:C:2006:544, paragraph 47.

${ }^{222}$ For example see judgement of 26 February 2019, X GmbH, C-135/17, EU:C:2019:136 regarding the comparability of CFC regulation with EU primary law.

${ }^{223}$ Aigner, H-J., Scheuerle, U., Stefaner, M. General Report. CFC Legislation. Domestic Provisions, Tax Treaties and EC Law. Edited by Lang, M. et al. Linde, 2004, page 52.

${ }^{224}$ Helminen, M. Is There a Future for CFC-regimes in the EU? INTERTAX, 2005. Volume 33, Issue 3, page 119.
} 
Convention. First, the aim of Arbitration Convention is to eliminate double taxation in connection with the adjustment of profits of associated enterprises in their commercial or financial relations. ${ }^{225} \mathrm{CFC}$ rules, however, do not adjust the profits resulting from related party transactions, instead they change the moment of taxation by the resident state. ${ }^{226}$ Moreover, the double taxation resulting from transfer pricing adjustments is typically caused by structural adjustments, which, however, tax authorities cannot make under CFC rules. ${ }^{227}$ Therefore, the double taxation resulting from the CFC rules is not comparable to double taxation arising from transfer pricing adjustments, thus, the Arbitration Convention is not proper source of law to eliminate such double taxation.

In addition to aforesaid, disputes of double taxation could also be solved by the Dispute Resolution Directive. Pursuant to the article 1, all disputes between Member States which arise from the interpretation and application of tax treaties are in the scope of the Dispute Resolution Directive. Thus, in order for the double taxation to be solved by the Dispute Resolution Directive, such double taxation must derive from a tax treaty.

As analyzed in section 4.1.2., domestic CFC rules are not conflicting with tax treaties and therefore state is entitled to attribute income to its resident taxpayers pursuant to domestic legislation, irrespective of any tax treaty in force. Therefore, provided that the income of a CFC would be taxed under article 7,10 or any other distribution rule of the OECD MC, ${ }^{228}$ the dispute arising from such taxation could be within the scope of Dispute Resolution Directive. Nevertheless, the Dispute Resolution Directive would not oblige Member State to provide relief for double taxation caused by i) participation criteria; ii) effective tax rate; or iii) loss carry forward as pursuant to the OECD approach, examined in section 4.1.2., the state of residence would be required to credit only taxes paid by the CFC and not by subsidiaries or sub-subsidiaries of the CFC. Thus, the double taxation under dispute would not arise from the interpretation and application of a tax treaty, which by following the OECD MC article 23B, would not require tax credit beyond taxes paid by the CFC and would therefore not be within the scope of the Dispute Resolution Directive. Hence, the Dispute Resolution Directive would not be an applicable source of law to eliminate double taxation caused by CFC rules of the ATAD.

\footnotetext{
${ }^{225}$ Arbitration Convention, preamble and article 4.

${ }^{226}$ Blum, D. W., op. cit., page 309.

${ }^{227}$ Kuźniacki, B., op. cit., page 766.

${ }^{228}$ Rust, A. National Report Germany., op. cit., page 267.
} 


\section{CONCLUSIONS}

Due to the de minimis nature of the ATAD and Member States' increased number of opportunities to tax, its implementation is leading to the conflict of norms and thereby also to potential double taxation. Pursuant to the recital 5 of the ATAD, the drafters were aware of the potential double tax burden, nevertheless, as regards the rule on interest deduction limitation and CFC rules, in majority of cases there is no obligation to eliminate double taxation under the ATAD. In cases the ATAD does not provide relief for double taxation itself, it is up to a taxpayer to identify the correct source of law on the basis of which the double taxation could be eliminated.

Double taxation resulting from the interest deduction limitation rule of the ATAD has its origin in qualification conflict. Economic double taxation derives when the Member State of a borrower denies the deduction of borrowing costs while the Member State of a creditor still taxes the received interest income. The ATAD foresees a mechanism of carry forward and back of non-deductible borrowing costs or unused interest capacity. However, the provision is not mandatory for Member States to implement.

Should there be no carry forward and back mechanism, the economic double taxation could be solved under the article 9 of OECD MC as by denying the deduction of borrowing costs, the Member State is deemed to adjust the profits of its resident. Nevertheless, should the Member State of the creditor disagree with the corresponding adjustment, Member States can seek solution under a mutual agreement procedure. In case the mutual agreement procedure turns out to be unsuccessful, Member

States are obliged to continue with the arbitration, provided that the tax treaty includes the clause of mandatory arbitration.

Juridical double taxation arising from the fact that domestic interest limitation rule does not prohibit the taxation of income under article 11 of the OECD MC, is usually solved by the article 23 of OECD MC. Within the EU, the aforementioned juridical double taxation would be avoided in case the payment falls under the Interest and Royalty Directive which prohibits the imposition of withholding taxes on outbound interest payments.

In addition, disputes of double taxation resulting from the rule on interest deduction limitation could also be solved under the Arbitration Convention as a dispute arising from transfer pricing adjustment, or under the Dispute Resolution Directive as a dispute deriving from the interpretation and application of a tax treaty. Since the deduction of borrowing costs is limited equally in domestic and cross-border situations, EU primary law would not provide any solution for double taxation.

However, it is important to note that article 9 of the OECD MC, the Arbitration Convention and the Dispute Resolution Directive deal only with cross-border loans granted between associated parties. Therefore, double taxation resulting from the interest deduction limitation on a loan granted domestically or between non-related parties, no solution for double taxation is available. Furthermore, as regards the Arbitration Convention and the Dispute Resolution Directive, also loans where one party is located outside of the EU are out of the scope. Therefore, the problem of unsolved double taxation resulting from the interest deduction limitation rule of the ATAD would require a further research on 
how the implementation of this rule without mandatory carry forward and back rules would not conflict with the principles of international taxation.

Besides interest deduction limitation rule, economic double taxation could also arise from the implementation of CFC rules which aim to re-attribute the undistributed harmful income of a CFC to its parent company in the EU. Pursuant to the CFC rules of the ATAD, Member States are not required to provide any relief in case the double taxation results from the i) application of participation criteria by several Member States; ii) determination of an effective tax rate; or iii) loss carry forward. The same conclusion applies also as regards the OECD MC which does not require Member States to credit taxes paid by the subsidiaries or sub-subsidiaries of the CFC or its parent company.

Furthermore, despite the potential discriminatory nature of the CFC rules, it is unlikely that the EU primary law would solve the problem of economic double taxation resulting from the implementation of CFC rules. The double taxation in question would also not be in breach with the EU secondary legislation such as the Parent-Subsidiary Directive.

Since the double taxation in question would not derive from structural adjustment like in case of transfer pricing adjustments, the Arbitration Convention would not be applicable source of law to solve the problem of double taxation. Furthermore, as the scope of Dispute Resolution Directive is limited to disputes arising from the interpretation and application of tax treaties, the Dispute Resolution Directive would be applicable only to solve the disputes regarding distributive rules under which the CFC income is taxed and questions regarding tax credit in amount of taxes paid by the CFC. However, disputes regarding the tax credit in amount of taxes paid by the subsidiaries or sub-subsidiaries of the CFC or its parent company would fall out of the scope.

To conclude, the OECD MC would be a reliable source of law to solve the juridical double taxation resulting from the implementation of interest deduction limitation rule of the ATAD. The OECD MC, the Arbitration Convention and the Dispute Resolution Directive would be correct sources of law to provide relief for economic double taxation resulting from the rule on interest deduction limitation. However, their applicability would be limited to situations where the deduction of borrowing costs is denied on cross-border loan between related parties. Examined double taxation deriving from the implementation of CFC rules of the ATAD would not be solved under any source of law scrutinized in this thesis. Thus, a further research is necessary to ascertain the ways Member States could implement CFC rules of the ATAD without causing double taxation. 


\section{BIBLIOGRAPHY}

Aigner, H-J., Scheuerle, U., Stefaner, M. General Report. CFC Legislation. Domestic Provisions, Tax Treaties and EC Law. Edited by Lang, M. et al. Linde, 2004.

Arnold, B. J. International Tax Primer. Third edition. Wolters Kluwer, 2018.

Ault, H. J., Issues Related to the Identification and Characteristics of the Taxpayer. Bulletin for International Taxation, 2002. Volume 56, No. 6.

Bizioli, G. Taking EU Fundamental Freedoms Seriously: Does the Anti-Tax Avoidance Directive Take Precedence over the Single Market? EC Tax Review, 2017. Volume 26, Issue 3.

Blum, D. W. Controlled Foreign Companies: Selected Policy Issues - or the Missing Elements of BEPS Action 3 and the Anti-Tax Avoidance Directive. INTERTAX, 2018. Volume 46, Issue 4.

Bonn, J. S. CFC Rules and Anti-Tax Avoidance Directive. EC Tax Review, 2017. Volume 26, Issue 3.

Chand, V. The Interaction of Domestic Anti-Avoidance Rules with Tax Treaties (with special references to the BEPS project). Tax Policy Series. Edited by Danon, R. Geneva/Zurich, 2018.

Confédération Fiscale Européenne. Opinion Statement FC 3/2016 on the European Commission's proposal for an Anti-Tax Avoidance Directive of 28 January 2016. Available online http://taxadviserseurope.org/wp-content/uploads/2018/05/CFE-Opinion-Statement-FC-3-2016-on-theAnti-Tax-Avoidance-Directive.pdf

Cordewener, A. The Interest and Royalty Directive. European Tax Law. Volume 1 - General Topics and Direct Taxation. 7th Student edition. Edited by Wattel, P., Marres, O., Vermuelen, H. Deventer: Wolters Kluwer, 2018.

Dahlberg, M., Wiman, B. General Report. The taxation of foreign passive income for groups of companies. IFA Cahiers, Volume 98A, 2013.

Danon, R. J. Conflicts of Attribution of Income Involving Trusts under the OECD Model Convention: The Possible Impact of the OECD Partnership Report. Intertax, 2004. Volume 32, Issue 5.

Danon, R. J., Salomé, H. Avoidance of Double Non-Taxation in Switzerland. Avoidance of Double Non-Taxation. Edited by Lang, M. Linde, 2003.

Danon, R. J. Some Observations on the Carve-Out Clause of Article 7(2)(a) of the ATAD with Regard to Third Countries. The Implementation of Anti-BEPS Rules in the EU: A Comprehensive Study. Edited by Pistone, P., Weber, D. IBFD, 2018.

De Broe, L. International Tax Planning and Prevention of Abuse. A Study under Domestic Tax Law, Tax Treaties and EC Law in Relation to Conduit and Base Companies. IBFD, Doctorial Series, 2008. Volume 14.

De Graaf, A., Visser, K-J., ATA Directive: Some Observations Regarding Formal Aspects. EC Tax Review, 2016. Volume 25, Issue 4.

De Lillo, F. The Impact of the EU Anti-Tax Avoidance Package on the Exercise of National Tax Sovereignty in European Tax Integration: Law, Policy and Politics. Edited by Pistone, P. IBFD, 2018. 
Debelva, F., Luts, J. The European Commission's Proposal for Double Taxation Dispute Resolution: Turning the Tide? Bulletin for International Taxation, 2017. Volume 71, No. 5.

Douma, S. Legal Research in International and EU Tax Law. Kluwer-Deventer, 2014.

Dourado, A. P. The EU Anti Tax Avoidance Package: Moving Ahead of BEPS? INTERTAX, Volume 44 , Issue $6 \& 7$.

Dourado, A. The Interest Limitation Rule in the Anti-Tax Avoidance Directive (ATAD) and the Net Taxation Principle. EC Tax Review, 2017. Volume 26, Issue 3.

Ginevra, G. The EU Anti-Tax Avoidance Directive and the Base Erosion and Profit Shifting (BEPS) Action Plan: Necessity and Adequacy of the Measures at EU level. INTERTAX, 2017. Volume 45, Issue 2 .

Govind, S. The New Face of International Tax Dispute Resolution: Comparing the OECD Multilateral Instrument with the EU Dispute Resolution Directive. EC Tax Review, 2018. Volume 27, Issue 6.

Govind, S., Turcan, L. Cross-Border Tax Dispute Resolution in the 21st century: A Comparative Study of Existing Bilateral and Multilateral Remedies. Derivatives \& Financial Instruments, 2017. Volume 19, No. 5.

Govind, S., Turcan, L. The Changing Contours of Dispute Resolution in the International Tax World: Comparing the OECD Multilateral Instrument and the Proposed EU Arbitration Directive. Bulletin for International Taxation, 2017. Volume 71, No. 3/4.

Govind, S., Zolles, S. The Anti-Tax Avoidance Directive. Introduction to European Tax Law on Direct Taxation, 5th edition. Edited by Lang, M. (Eds), Linde, 2018.

Gupta, V. K. Conflicts of Qualification and Conflicts of Allocation of Income. Conflicts of Qualification in Tax Treaty Law. Edited by Burgstaller, E., Haslinger, K. Linde, 2007.

Helminen, M. Is There a Future for CFC-regimes in the EU? INTERTAX, 2005. Volume 33, Issue 3.

Helminen, M. The Principle of Elimination of Double Taxation under EU Law - Does it Exist? Principles of Law: Function, Status and Impact in EU Tax Law. Edited by Cécile Brokelind. IBFD, 2014.

Hinnekens, L. The Uneasy Case and Fate of Article 293 Second Indent EC. INTERTAX, 2009. Volume 37, Issue 11.

Hoor, O.R., O’Donnell, K., Schmitz Merle, S., EU Commission Releases Draft Directive on BEPS: A Critical Analysis from a Luxembourg Perspective. European Taxation, 2016. Volume 56, No. 5.

IBFD Tax Glossary. Available online

https://online.ibfd.org/kbase/\#topic=doc\&url=/highlight/collections/itg/html/itg_classical_system.htm $1 \& q=$-classical \&WT.z_nav=Search

Ismer, R. Klaus Vogel on Double Taxation Conventions, 4th edition, edited by Reimer, E., Rust, A., 2015. Article 25.

Jones, J.F.A. et al. The Legal Nature of The Mutual Agreement Procedure Under the OECD Model Convention - I. British Tax Review, 1979. Vol. 1979, Issue 6. 
Jones, J.F.A. Qualification Conflicts: The Meaning of Application in Article 3(2) of the OECD Model. Festschrift für Karl Beusch zum 68. Geburtstag am 31. Oktober 1993. Edited by Beisse, H., Lutter, M., Närger, H. New York: de Gruyter.

Jones, J.F.A. Treaty Interpretation. Global Tax Treaty Commentaries. IBFD, 2018.

Kienberger, S. Avoidance of Double (Non-)Taxation and Art. 23A and B Paragraph 1 OECD MC. Conflicts of Qualification in Tax Treaty Law. Edited by Burgstaller, E., Haslinger, K. Linde, 2007.

Kofler, G. Klaus Vogel on Double Taxation Conventions, 4th edition, edited by Reimer, E., Rust, A., 2015. Article 9.

Kuźniacki, B. The Need to Avoid Double Economic Taxation Triggered by CFC Rules under Tax Treaties, and the Way to Achieve It. INTERTAX, 2015. Volume 43, Issue 12.

Lang, M. 2008 OECD Model: Conflicts of Qualification and Double Non-Taxation. Bulletin for International Taxation, 2009. Volume 63, No 5.

Lang, M. Introduction to the Law of Double Taxation Conventions (Second Revised Edition). IBFD, 2013.

Lang, M. The Application of the OECD Model Tax Convention to Partnerships. A Critical Analysis of the Report Prepared by the OECD Committee on Fiscal Affairs. Linde, 2000.

Lang, M. Qualification Conflicts. Global Tax Treaty Commentaries. IBFD, 2018.

Lobita, J. C. The ATAD's Interest Limitation Rule - A Step Backwards? European Taxation, 2019. Volume 59, No. 2/3.

Makhmudova, K. Conflicts of Qualification and Thin Capitalisation Rules. Conflicts of Qualification in Tax Treaty Law. Edited by Burgstaller, E., Haslinger, K. Linde, 2007.

Monsenego, J. Taxation of Foreign Business Income within the European Internal Market. An Analysis of the Conflict between the Objective of Achievement of the European Internal Market and the Principles of Territoriality and Worldwide Taxation. IBFD Doctorial Series, 2012. Volume 22.

Moser, T., Hentschel, S. The Provisions of the EU Anti-Tax Avoidance Directive Regarding Controlled Foreign Company Rules: A Critical Review Based on the Experience with the German CFC Legislation. INTERTAX, 2017. Volume 45, Issue 10.

Oxford English Dictionary. Available online - https://en.oxforddictionaries.com/

Pistone, B. The Settlement of Cross-Border Tax Disputes in the European Union. European Tax Law. Volume 1 - General Topics and Direct Taxation. 7th Student edition. Edited by Wattel, P., Marres, O., Vermuelen, H. Deventer: Wolters Kluwer, 2018.

Pit, H. M. Dispute Resolution in the EU. The EU Arbitration Convention and the Dispute Resolution Directive. IBFD, Doctorial Series, 2018. Volume 42.

Pleil, C., Schwibinger, S. Confronting Conflicts of Qualification in Tax Treaty Law: The Principle of Common Interpretation and the New Approach Revisited. World Tax Journal, 2018. Volume 10, No 3.

Rigaut, A. Anti-Tax Avoidance Directive (2016/1164): New EU Policy Horizons. European Taxation, 2016. Volume 56, No 11. 
Rust, A. CFC Legislation and EC Law. INTERTAX, 2008. Volume 36, Issue 11.

Rust, A. Klaus Vogel on Double Taxation Conventions, 4th edition, edited by Reimer, E., Rust, A., 2015. Article 1.

Rust, A. Klaus Vogel on Double Taxation Conventions, 4th edition, edited by Reimer, E., Rust, A., 2015. Article 23.

Rust, A. National Report Germany. CFC Legislation. Domestic Provisions, Tax Treaties and EC Law. Edited by Lang, M. et al. Linde, 2004.

Rust, A. The New Approach to Qualification Conflicts has its Limits. Bulletin for International Taxation, 2003. Volume 57, No 2.

Smit, D. The Anti-Tax-Avoidance Directive (ATAD). European Tax Law. Volume 1 - General Topics and Direct Taxation. 7th Student edition. Edited by Wattel, P., Marres, O., Vermuelen, H. Deventer: Wolters Kluwer, 2018.

Szudoczky, R., Weber, D. Constitutional Foundations: EU Tax Competence; Legal Basis for Tax Integration; Sources and Enactment of EU Tax Law. European Tax Law. Volume 1 - General Topics and Direct Taxation. 7th Student edition. Edited by Wattel, P., Marres, O., Vermuelen, H. Deventer: Wolters Kluwer, 2018.

Tell, M. Interest Limitation Rules in the Post-BEPS Era. INTERTAX, 2017. Volume 45, Issue 11.

United Nations, Vienna Convention on the Law of Treaties, 23 May 1969, United Nations, Treaty Series, vol. 1155.

Van Hulle, G. Current Challenges for EU Controlled Foreign Company Rules. Bulletin for International Taxation, 2017. Volume 71, No. 12.

Van Os, P. Interest Limitation under the Adopted Anti-Tax Avoidance Directive and Proportionality. EC Tax Review, 2016. Volume 25, Issue 5.

Van Raad, K. General Report. Recognition of foreign enterprises as taxable entities. IFA Cahiers, Volume 73A, 1988.

Vogel, K. Conflicts of Qualification: The Discussion is not Finished. Bulletin for International Taxation, 2003. Volume 57, No 2.

Vogel, K., Rust, A. Klaus Vogel on Double Taxation Conventions, 4th edition, edited by Reimer, E., Rust, A., 2015. Introduction.

Wattel, P., Brokelind, C. Free Movement and Tax Base Integrity. European Tax Law. Volume 1 General Topics and Direct Taxation. 7th Student edition. Edited by Wattel, P., Marres, O., Vermuelen, H. Deventer: Wolters Kluwer, 2018.

Wattel, P. Conceptual Background of the CJEU Case Law in Direct Tax Matters. European Tax Law. Volume 1 - General Topics and Direct Taxation. 7th Student edition. Edited by Wattel, P., Marres, O., Vermuelen, H. Deventer: Wolters Kluwer, 2018.

Wattel, P. Relevance of (Deviations from) the OECD Model and Commentary in ECJ Income Tax Case Law. Departures from the OECD Model and Commentaries. Reservations, observations and positions in EU law and tax treaties. Edited by Maisto, G. IBFD, 2014. 
Weninger, P. The Role of Arbitration in Resolving Qualification Conflicts under Tax Treaties. Conflicts of Qualification in Tax Treaty Law. Edited by Burgstaller, E., Haslinger, K. Linde, 2007.

Äimä, K. Key practical issues to eliminate double taxation of business income. Classification Conflicts: The Cross-Border Tax Treatment of the Profit Share of Limited Partners. IFA Cahiers, Volume 96B, 2011.

$\underline{\text { OECD materials }}$

OECD. Limiting Base Erosion Involving Interest Deductions and Other Financial Payments, Action 4. Final Report, OECD/G20 Base Erosion and Profit Shifting Project. OECD Publishing, Paris, 2015.

OECD. Model Tax Convention on Income and on Capital 2017 (Full Version). OECD Publishing, 2019.

OECD. Thin Capitalisation (adopted by the OECD Council on 26 November 1986). Reproduced in the Volume II of the full version of the OECD Model Tax Convention at page R(4)-1.

Tax treaties: update to OECD Model Tax Convention released. OECD press release from 18.12.2017. Available online - http://www.oecd.org/tax/treaties/tax-treaties-2017-update-to-oecd-model-taxconvention-released.htm

European Union legislation and documents

90/436/EEC: Convention on the elimination of double taxation in connection with the adjustment of profits of associated enterprises. Official Journal L 225, 20.8.1990, pages 10-24.

Commission of The European Communities. Communication from The Commission To The Council, The European Parliament And The European Economic And Social Committee on the work of the EU Joint Transfer Pricing Forum in the period March 2007 to March 2009 and a related proposal for a revised Code of Conduct for the effective implementation of the Arbitration Convention (90/436/EEC of 23 July 1990). 14.9.2009. COM(2009) 472 final.

Commission of The European Communities. Taxation in the European Union. 20.03.1996. SEC(96) 487 final.

Communication from The Commission to The European Parliament and The Council. Anti-Tax Avoidance Package: Next steps towards delivering effective taxation and greater tax transparency in the EU. COM/2016/023 final.

Consolidated version of the Treaty on European Union. Official Journal C 326, 26.10.2012, pages 13390.

Consolidated version of the Treaty on the Functioning of the European Union. Official Journal C 326, 26.10.2012, pages 47-390.

Council Directive (EU) 2016/1164 of 12 July 2016 laying down rules against tax avoidance practices that directly affect the functioning of the internal market. Official Journal L 193, 19.7.2016, pages 114.

Council Directive (EU) 2017/952 of 29 May 2017 amending Directive (EU) 2016/1164 as regards hybrid mismatches with third countries. Official Journal L 144, 7.6.2017, pages 1-11. 
Council Directive 2003/49/EC of 3 June 2003 on a common system of taxation applicable to interest and royalty payments made between associated companies of different Member States. Official Journal L 157, 26.6.2003, pages 49-54.

Council Directive 2011/96/EU of 30 November 2011 on the common system of taxation applicable in the case of parent companies and subsidiaries of different Member States. Official Journal L 345, 29.12.2011, pages 8-16.

Council Directive 2017/1852 of 10 October 2017 on tax dispute resolution mechanisms in the European Union, Official Journal L 265, 14.10.2017, p. 1-14.

Council of the European Union. Note on Dispute Resolution Mechanisms - Proposal for a Council Directive on Double Taxation Dispute Resolution Mechanisms in the European Union, General approach. 12 May 2017, 9011/17.

Revised Code of Conduct for the effective implementation of the Convention on the elimination of double taxation in connection with the adjustment of profits of associated enterprises. Official Journal C 322, 30.12.2009, pages 1-10.

Case law

Judgement of 26 February 2019, N Luxembourg 1, joined cases C-115/16, C-118/16, C-119/16 and C299/16, EU:C:2019:134.

Judgement of 26 February 2019, X GmbH, C-135/17, EU:C:2019:136.

Judgement of 12 September 2017, Austria vs Germany, C-648/15, EU:C:2017:664.

Judgement of 10 June 2015, X AB, C-686/13, EU:C:2015:375.

Judgement of 13 November 2012, Test Claimants in the FII Group Litigation, C-35/11, EU:C:2012:707.

Judgement of 21 July 2011, Scheuten Solar Technology, C-397/09, EU:C:2011:499.

Judgement of 16 July 2009, Damseaux, C-128/08, EU:C:2009:471.

Judgement of 12 February 2009, Margarete Block, C-67/08, EU:C:2009:92.

Judgement of 6 December 2007, Columbus Container Services, C-298/05, EU:C:2007:754.

Judgement of 8 November 2007, Amurta, C-379/05, EU:C:2007:655.

Judgement of 12 September 2006, Cadbury Schweppes, C-196/04, EU:C:2006:544.

Judgement of 12 May 1998, Gilly, C-336/96, EU:C:1998:221. 